\title{
ARTIKELEN
}

\section{Een universeel rekenmodel voor bedrijfstak(cao- en pensioen)regelingen?}

\author{
M.J.H. Halsema
}

1

Inleiding

Onderwerpen als 'pensioenrecht' en 'cao-recht' worden doorgaans niet beschouwd als de spannendste binnen het arbeidsrecht. Als er dan ook nog een 'rekenmodel' met wiskundige formules wordt geïntroduceerd, bestaat de kans dat de gemiddelde arbeidsrechtjurist snel doorbladert. Toch is het van belang om van deze bijdrage kennis te nemen, eenvoudigweg omdat de meeste werkgevers en werknemers in Nederland erdoor geraakt worden. Ter geruststelling: deze bijdrage is ook leesbaar zonder bestudering van de wiskundige formules. Veruit de meeste ${ }^{1}$ werknemers en werkgevers in Nederland zijn gebonden aan bedrijfstak(cao- en pensioen)regelingen ${ }^{2}$ (hierna: bcp-regelingen). De tekst van de werkingssfeerbepalingen van die regelingen moet duidelijk zijn om voor verbindendverklaring door de minister in aanmerking te komen. ${ }^{3}$ Mede op grond van die tekst dient immers te kunnen worden bepaald of een (onderneming van een) werkgever onder de werkingssfeer van bcp-regelingen valt. Blijkens de rechtspraak en literatuur daarover is echter niet altijd volkomen duidelijk of, en zo ja, waarom een werkgever onder de werkingssfeer van bcp-regelingen valt. Het is al gebleken dat het toepassen van het in de literatuur en de rechtspraak voorkomende criterium 'de kern en het zwaartepunt van de ondernemingsactiviteiten' niet altijd het juiste antwoord oplevert. Zo zijn de werknemers van Bam Geleiderail in een zaak waarover de Hoge Raad oordeelde, betrokken bij het aanleggen van vangrails en komt zowel het gerechtshof te Amsterdam als de A-G met toepassing van dat criterium tot

1 Zo'n 90\% van de Nederlandse werknemers valt onder een collectieve pensioenregeling en 92\% van de Nederlandse werknemers is gebonden door en aan een cao. Pensioenfederatie, Voor elkaar, Ontwikkeling en positie van collectieve pensioenen in Nederland, november 2011, p. 15. E. Lutjens, Tien jaar Pensioenwet, ArA 2017/2, p. 33; Asser/Lutjens 7-XI 2016/257; A.Ph.C.M. Jaspers \& M.F. Baltussen (red.), De toekomst van het cao-recht (reeks VvA 39), Deventer: Kluwer 2011, p. 275; F.B.J. Grapperhaus, Terug de polder in, pleidooi voor een werkende arbeidsmarkt, Amsterdam: uitgeverij Bert Bakker 2013, p. 71 en 72; M. Rojer, Cao of geen cao, dat is de vraag, TRA 2015/57.

2 Zie voor dit begrip 'bedrijfstak(cao- en pensioen)regelingen' HR 27 mei 2011, ECLI:NL:HR: 2011:BQ0010, r.o. 3.1, NJ 2011/258, (Mt/Bam).

3 Toetsingskader algemeenverbindendverklaring cao-bepalingen (Stcrt. 22 september 2017, nr. 52963, hierna: Toetsingskader-avv), par. 1, 4.5 en 5. Beleidsregel toetsingskader Wet Bpf 2000 (Stcrt. 31 augustus 2017, nr. 49113, hierna: Toetsingskader-bpf), par. 2. A.T.J.M. Jacobs, Collectief arbeidsrecht (Monografieën Sociaal Recht, nr. 28), 2017, par. 6.2.4. 
een onjuist oordeel. ${ }^{4}$ De annotator verzucht bij het arrest van de Hoge Raad dat 'die uitspraak pijnlijk duidelijk maakt hoe lastig het is zekerheid te verschaffen over de uitleg van werkingssfeerbepalingen terwijl dit wel is wat regelmatig wordt gevraagd door cliënten' en voegt daaraan toe dat 'men er geen vergif op kan innemen, en men niet te gevoelig moet zijn voor slapeloze nachten'. ${ }^{5}$ Het gerechtshof te Den Haag lijkt vervolgens in de verwijzingszaak bij de beoordeling van de werkingssfeer het doel van de onderneming voorop te stellen. ${ }^{6}$ In een andere zaak lijkt datzelfde gerechtshof het doel van de onderneming weer geheel niet van belang te achten. ${ }^{7}$ In de uitspraken in de zaak tussen Care 4 Care Human Resources B.V. (hierna: C4C) en Stichting Pensioenfonds voor Personeelsdiensten (StiPP) komt weer wel het doel van de onderneming aan de orde, te weten het uitzenden van werknemers. In die zaak komt echter niet aan de orde dat een volledig in de bedrijfstak Zorg en Welzijn gespecialiseerde uitzendwerkgever (zoals C4C) in beginsel geen werkgever in de zin van de bcp-regelingen voor Uitzendkrachten is, maar onder de werkingssfeer van de bcp-regelingen van Zorg en Welzijn valt. ${ }^{8}$ Al deze onduidelijkheid en onzekerheid brengt risico's met zich. Een werkgever die ten onrechte geen bcp-regelingen toepast, kan bijvoorbeeld met terugwerkende kracht verplicht worden de binnen de bedrijfstak toepasselijke bedrijfstakcao (hierna: bc) na te komen en pensioenpremies en cao-bijdragen aan bcp-fondsen te voldoen. ${ }^{9}$ Een bedrijfstakpensioenfonds (hierna: bpf) dient bijvoorbeeld te voorkomen dat het later een pensioen moet uitkeren terwijl daar geen pensioenpremiebetalingen tegenover staan. ${ }^{10}$ Op welke wijze kan nu meer duidelijkheid en zekerheid worden verschaft over de uitleg van werkingssfeerbepalingen van bcpregelingen, zodat dergelijke risico's worden beperkt? In 2015 is een systematische bundeling van (de werkingssfeerbepalingen in) die regelingen verschenen om de toegankelijkheid daarvan te bevorderen. ${ }^{11}$ Indien er een formule uit de bepalingen van die regelingen valt te distilleren waarmee de werkingssfeer kan worden berekend, dan kunnen de risico's gemoeid met de uitleg van werkingssfeerbepalingen worden beperkt. Het is dus de vraag of tot een model kan worden gekomen voor de berekening van de werkingssfeer van bcp-regelingen. Dit is mogelijk

4

6 Gerechtshof Den Haag 2 december 2014, ECLI:NL:GHDHA:2014:3989, NJ 2016/465 (Mt/Tussendiepen vh. Bam). Zie voor de cassatiezaak HR 23 september 2016,ECLI:NL:HR:2016:2170, JAR 2016/248 (artikel 81 lid 1 RO).

7 Gerechtshof Den Haag 6 juni 2017, ECLI:NL:GHDHA:2017:1513, PJ 2017/111 (Mt/Unis).

8 M.J.H. Halsema, De grondpositie van de gespecialiseerde uitzendwerkgever in de Nederlandse polder, TAP 2016/6, nr. 266; K. Dorenbos, R. Mourits \& C. Waterman, Care4Care/StiPP: vloek of zegen?, Tijdschrift voor Arbeid en Onderneming 2016, december; L.G. Verburg, De uitzendwereld na C4C: bespiegelingen over heden en toekomst, ArA 2017/1. Inleen- en uitleensituaties blijven in deze bijdrage buiten beschouwing.

9 Gerechtshof Den Bosch 15 april 2008, ECLI:NL:GHSHE:2008:BD3912, RAR 2008/115 (Frissland B.V./werknemer).

10 HR 3 februari 2012, ECLI:NL:HR:2012:BT8462, NJ 2012/93 (Bpf Beroepsvervoer/Labots). Asser/Lutjens 7-XI 2016/219 en 295.

11 M.J.H. Halsema, De werkingssfeer van bedrijfstak(cao- en pensioen)regelingen in Nederland, Den Haag: Boom Juridische uitgevers 2015. 
indien er (a) patronen en relaties kunnen worden aangewezen binnen en tussen deze regelingen, en (b) daaraan variabelen kunnen worden gekoppeld: ${ }^{12}$

a Een 'variabele' is een eenheid (grootheid) die steeds een andere waarde (getal) kan hebben. Zo kan bijvoorbeeld zowel het 'aantal werknemers' als het 'aantal met hen overeengekomen arbeidsuren' een 'variabele' zijn. Het begrip 'variabele' is het tegenovergestelde van het begrip 'constante'. ${ }^{13}$

b De variabelen zijn de verschillende elementen van een 'verzameling'. Zo bezien vormen zowel 'werknemers' als 'overeengekomen arbeidsuren' binnen een onderneming ieder een verzameling.

c De systematische bundeling van (de werkingssfeerbepalingen in) de bcp-regelingen kan in zijn geheel als een 'verzameling' worden gezien, en de bcp-regelingen daarin kunnen (per te onderscheiden bedrijfstak) als een 'deelverzameling' daarvan worden gezien.

Hierna wordt ingegaan op de (systematiek van de) werkingssfeer van de oudste verplicht gestelde bedrijfstakregelingen, te weten die binnen de Landbouw, de Metalektro en de Metaal en Techniek. ${ }^{14}$ Op basis van de patronen en relaties binnen en tussen deze bedrijfstakken wordt een model geïntroduceerd voor de berekening van de op een werkgever toepasselijke werkingssfeer van bcp-regelingen. Dit rekenmodel zal van belang zijn voor de uitleg van de werkingssfeer van de overige in deze bijdrage vermelde regelingen. Natuurlijk zal ook worden ingegaan op de verhouding van dit model tot het in de literatuur en de rechtspraak voorkomende criterium 'de kern en het zwaartepunt van de ondernemingsactiviteiten'. Allereerst wordt hierna aandacht besteed aan de achtergrond van de bcpregelingen en volgt een overzicht daarvan.

Bedrijfstak(cao- en pensioen)regelingen

Er kan in Nederland worden gesproken van een 'bedrijfstakgewijze organisatie' van het bedrijfsleven. ${ }^{15}$ De wettelijk verplichte deelneming in een bpf wordt in 1949 mogelijk gemaakt met de Wet verplichte deelneming in een bedrijfspensioenfonds (hierna: Wet Bpf). ${ }^{16}$ Deze bedrijfstakgewijze inrichting van pensioenvoorzieningen sluit aan bij de ontwikkeling die in 1937 in gang is gezet met de Wet op het algemeen verbindend en het onverbindend verklaren van bepalingen

12 Van Dale Online: patroon: structuur die in een bepaalde situatie inzicht verschaft; relatie: betrekking waarin personen, zaken, begrippen tot elkaar staan; variabele: wiskunde, grootheid die in waarde enz. kan veranderen.

13 Van Dale Online: constante: onveranderlijke grootheid.

14 Van Dale Online: systematiek: leer mbt. een systeem of systemen, m.n. betreffende een systeem van rangschikking; idem Van Dale Groot Woordenboek van de Nederlandse taal, veertiende, herziene uitgave. Tenzij anders vermeld, wordt in deze bijdrage naar deze laatste editie van Van Dale verwezen.

15 Kamerstukken II 1948/49, 785, 5, p.12. E. Lutjens, De Wet Bpf, 50 jaar verplichte bedrijfspensioenfondsen (Pensioenmonografieën, nr. 7), Deventer: Kluwer 1999, p. 5 e.v., 15 en 21.

16 Wet Bpf 1949 (Stb. 1949, J 121), in 2001 vervangen door de Wet verplichte deelneming in een bedrijfstakpensioenfonds, de Wet Bpf 2000 (Stb. 2000, 628). Asser/Lutjens 7-XI 2016/3. 
van cao's (hierna: Wet AVV) ${ }^{17}$ en de op het Buitengewoon Besluit Arbeidsverhoudingen $^{18}$ gebaseerde loonregelingen. ${ }^{19}$ Het wordt aan het initiatief van het bedrijfsleven overgelaten te bepalen of er een bpf moet komen. ${ }^{20}$ Onder de werking van de Wet Bpf komen de bpf's tot groei en bloei. ${ }^{21}$ Het eerste bpf dat met toepassing van de Wet Bpf verplicht wordt gesteld, betreft per 1 mei 1949 het bpf Landbouw (hierna: bpf Lb). ${ }^{22}$ Met ingang van 15 november 1949 wordt de verplichtstelling (hierna: vb) van het bpf Metaalnijverheid (Groot Metaal, thans Metalektro, hierna: bpf Me) van kracht. ${ }^{23}$ Met ingang van 1 januari 1950 volgt de vb van het bpf Kleine Metaalnijverheid (thans bpf Metaal en Techniek, hierna: bpf Mt). ${ }^{24}$ De groei van het aantal verplicht gestelde bpf's zet zich hierna gestaag door. Al in 1953 wijst Offerhaus ${ }^{25}$ er op dat de bpf's 'een realiteit vormen, waaraan niet voorbijgegaan kan worden en het uitermate moeilijk en niet anders dan ten koste van vele nadelen mogelijk zal zijn, hen te laten verdwijnen'. Figuur 1 geeft inzicht in de groei van de bpf's gedurende de periode 1949 tot $2017 .{ }^{26}$

17 Van het avv-instrument is ten opzichte van bpf's nimmer gebruikgemaakt. Met de Wet Bpf 1949 valt de betekenis van (artikel 2 van) de Wet AVV (25 mei 1937, Stb. 801) voor bpf's weg. Dan ontstaat het beleid pensioenbepalingen in cao's van verbindendverklaring uit te sluiten. Vgl. Toetsingskader-avv, par. 4.3.

18 Per 5 oktober 1945 (Stb. F 214).

19 Lutjens 1999, p. 5 e.v. Zie voor de ontwikkelingen die hebben geleid tot de totstandkoming van de Wet op de collectieve arbeidsovereenkomst (24 december 1927, Stb. 415, hierna: Wet cao), de Wet AVV en de naoorlogse ontwikkelingen op het gebied van collectieve arbeidsvoorwaardenvorming A. Stege, De cao en het regelingsbereik van de sociale partners, Deventer: Kluwer 2004, hoofdstuk 2 en 3.

20 Tweede Kamer 1 februari 1949, p. 1100. Met de Wet Bpf 1949 werd geenszins beoogd voor alle werknemers een pensioen te verzekeren. De Wet Bpf 1949 werd afgezet tegen het streven om te komen tot een algemene ouderdomsvoorziening, hetgeen later de AOW is geworden. De Wet Bpf 1949 werd gezien als eerste stap op weg naar een algehele regeling van de toekomstige oudedagsvoorziening. Lutjens 1999, p. 16.

21 Lutjens 1999, p. 53.

22 Stcrt. 31 mei 1949, nr. 104 (met terugwerkende kracht in werking).

23 Stcrt. 15 november 1949, nr. 223.

24 Stcrt. 28 februari 1950, nr. 42 (met terugwerkende kracht in werking).

25 E.J. Offerhaus, Bedrijfspensioenfondsen, Groningen 1953, p. 1 en 2. Zie voor een beschrijving van het Nederlandse pensioenstelsel Asser/Lutjens 7-XI 2016/5 e.v.

26 In de periode 1952-1963 valt blijkens figuur 1 de grootste stijging van het aantal bpf's te zien. Binnen deze periode valt vooral in de jaren 1956 (20 bpf's) tot 1958 (38 bpf's) een grote stijging van het aantal bpf's te zien. Dit kan verklaard worden door het in werking treden van de AOW in 1957, waarmee een hecht fundament onder de aanvullende pensioenen werd gelegd. Zie voor de periode 1949 tot 1996 de tabel in Lutjens 1999, p. 55 en 56. 


\section{Figuur 1 Aantal bpf's van 1949 tot 2017}

$\begin{array}{ll}\text { Periode } & \text { Aantal } \\ 1949-1951 & 02-08 \\ 1952-1958 & 12-38 \\ 1959-1963 & 46-55 \\ 1964-1996 & 60-66 \\ 1997-2000 & 66-67 \\ 2001-2006 & 67-78 \\ 2007-2017 & 78-54\end{array}$

Er zijn 54 verplicht gestelde bpf's in $2016 .{ }^{27}$ De bpf's zijn inmiddels, gemeten in aantal deelnemende werknemers, goed voor het belangrijkste onderdeel van de aanvullende pensioenen. ${ }^{28}$ Hierbij speelt een rol dat de vele inmiddels tot stand gekomen bedrijfstak-cao's een verplichting tot deelneming in een bpf vermelden. ${ }^{29} \mathrm{Al}$ in 1954 zegt Mannoury over de cao's dat deze 'tamelijk troebel, ondoorzichtig en ware leges barbarorum zijn die de uitlegger voor welhaast onoverkomelijke moeilijkheden plaatsen'. ${ }^{30}$ Figuur 2 beoogt meer inzicht te geven in de (systematiek van de) gedurende decennia geëvolueerde bcp-regelingen.

27 Kamerstukken II 2017/18, 34801, 3.

28 Asser/Lutjens 7-XI 2016/257.

29 Vgl. Halsema 2015.

30 J. Mannoury, De juridische techniek van de collectieve arbeidsovereenkomst (I), SMA 1954, p. 340. Zie voor een beschrijving van het Nederlandse cao-stelsel Asser/Heerma van Voss 7-V 2015/533 e.v.; W.J.P.M. Fase \& J. van Drongelen, Cao-recht, Deventer: Kluwer 2004. 


\section{Figuur 2 De systemen van bedrijfstak(cao-en pensioen)regelingen ${ }^{31}$ in} Nederland ${ }^{32}$

\begin{tabular}{|c|c|c|c|c|c|c|}
\hline $\begin{array}{c}\text { 1. Lb } \\
\text { Landbouw }\end{array}$ & $\begin{array}{c}\text { 2. Me } \\
\text { Metalektro }\end{array}$ & $\begin{array}{c}\text { 3. Mt } \\
\text { Metaal en } \\
\text { techniek }\end{array}$ & $\begin{array}{c}\text { 4. Sb } \\
\text { Slagersbedrijf }\end{array}$ & $\begin{array}{c}\text { 5. Sa } \\
\text { Schilders-, } \\
\text { afwerkings- en } \\
\text { glaszetbedrijf }\end{array}$ & $\begin{array}{c}\text { 6. Bn } \\
\text { Bouw- } \\
\text { nijverheid }\end{array}$ & $\begin{array}{c}\text { 7. Mi } \\
\text { Mode-, } \\
\text { interieur-, } \\
\text { tapijt- en } \\
\text { textielindustrie }\end{array}$ \\
\hline $\begin{array}{c}\text { 8. Hh } \\
\text { Houthandel }\end{array}$ & $\begin{array}{c}\text { 9. Bb } \\
\text { Bakkers- } \\
\text { bedrijf }\end{array}$ & $\begin{array}{c}\mathbf{1 0 .} \mathbf{K v} \\
\text { Koopvaardij }\end{array}$ & $\begin{array}{c}\text { 11. Mn } \\
\text { Medewerkers } \\
\text { in het notariaat }\end{array}$ & $\begin{array}{c}\text { 12. Mm } \\
\text { Meubel- } \\
\text { industrie en } \\
\text { meubilerings- } \\
\text { bedrijven }\end{array}$ & $\begin{array}{l}\text { 13. Gb } \\
\text { Grafische } \\
\text { bedrijven }\end{array}$ & $\begin{array}{c}\text { 14. Vg } \\
\text { Vlees, } \\
\text { vleeswaren- en } \\
\text { gemakvoeding } \\
\text { industrie }\end{array}$ \\
\hline $\begin{array}{c}\text { 15. Ba } \\
\text { Baggerbedrijf }\end{array}$ & $\begin{array}{l}\text { 16. Bp } \\
\text { Betonproduc- } \\
\text { tenindustrie }\end{array}$ & $\begin{array}{c}\text { 17. Hi } \\
\text { Houtver- } \\
\text { werkende } \\
\text { industrie en } \\
\text { jachtbouw }\end{array}$ & $\begin{array}{c}\text { 18. Ma } \\
\text { Medewerkers } \\
\text { apotheken }\end{array}$ & $\begin{array}{c}\text { 19. Mp } \\
\text { Media PNO }\end{array}$ & $\begin{array}{c}\text { 20. Ab } \\
\text { Architecten- } \\
\text { bureaus }\end{array}$ & $\begin{array}{c}\text { 21. Hb } \\
\text { Handel in } \\
\text { bouw- } \\
\text { materialen }\end{array}$ \\
\hline $\begin{array}{c}\text { 22. Gv } \\
\text { Groothandel in } \\
\text { vlakglas en } \\
\text { verf, glas- } \\
\text { bewerkings- en } \\
\text { glazenierbedrijf }\end{array}$ & $\begin{array}{l}\text { 23. Wc } \\
\text { Woning- } \\
\text { corporaties }\end{array}$ & $\begin{array}{l}\text { 24. Di } \\
\text { Drank- } \\
\text { industrie }\end{array}$ & $\begin{array}{l}\text { 25. Sm } \\
\text { Schoen- } \\
\text { makerij }\end{array}$ & $\begin{array}{c}\text { 26. Zi } \\
\text { Zoetwaren- } \\
\text { industrie }\end{array}$ & $\begin{array}{l}\text { 27. Hc } \\
\text { Horeca en } \\
\text { catering }\end{array}$ & $\begin{array}{l}\text { 28. Tv } \\
\text { Textiel- } \\
\text { verzorging }\end{array}$ \\
\hline $\begin{array}{l}\text { 29. Bw } \\
\text { Beroeps- } \\
\text { vervoer over } \\
\text { de weg }\end{array}$ & $\begin{array}{c}\text { 30. Av } \\
\text { Agrarische en } \\
\text { voedselvoor- } \\
\text { zieningshandel }\end{array}$ & $\begin{array}{l}\text { 31. Gl } \\
\text { Groothandel in } \\
\text { levens- } \\
\text { middelen }\end{array}$ & $\begin{array}{l}\text { 32. Ng } \\
\text { Nederlandse } \\
\text { groothandel }\end{array}$ & $\begin{array}{c}\text { 33. Tt } \\
\text { Tandtechniek }\end{array}$ & $\begin{array}{c}\text { 34. Lm } \\
\text { Levensmid- } \\
\text { delenbedrijf }\end{array}$ & $\begin{array}{c}\text { 35. Sg } \\
\text { Schoonmaak- } \\
\text { en glazen- } \\
\text { wassersbedrijf }\end{array}$ \\
\hline $\begin{array}{l}\text { 36. Wn } \\
\text { Wonen }\end{array}$ & $\begin{array}{c}\mathbf{3 7 .} \mathbf{K b} \\
\text { Kappers- } \\
\text { bedrijf }\end{array}$ & $\begin{array}{l}\text { 38. Zw } \\
\text { Zorg en } \\
\text { welzijn }\end{array}$ & $\begin{array}{c}\text { 39. Dh } \\
\text { Detailhandel }\end{array}$ & $\begin{array}{c}\text { 40. Rb } \\
\text { Rijn- en } \\
\text { binnenvaart }\end{array}$ & $\begin{array}{c}\text { 41. Ob } \\
\text { Openbare } \\
\text { bibliotheken }\end{array}$ & $\begin{array}{c}\text { 42. Bw } \\
\text { Banden- en } \\
\text { wielenbranche }\end{array}$ \\
\hline $\begin{array}{l}\text { 43. Sl } \\
\text { Schoen-, leder- } \\
\text { en lederwaren- } \\
\text { industrie }\end{array}$ & $\begin{array}{l}\text { 44. Si } \\
\text { Sigaren- } \\
\text { industrie }\end{array}$ & $\begin{array}{c}\text { 45. } \mathrm{Pb} \\
\text { Particuliere } \\
\text { beveiliging }\end{array}$ & $\begin{array}{c}\text { 46. Rb } \\
\text { Reisbranche }\end{array}$ & $\begin{array}{c}\text { 47. Br } \\
\text { Brandstoffen- } \\
\text { bedrijf }\end{array}$ & $\begin{array}{c}\text { 48. } \mathbf{T g} \\
\text { Technische } \\
\text { groothandel }\end{array}$ & $\begin{array}{c}\text { 49. Rc } \\
\text { Recreatie }\end{array}$ \\
\hline $\begin{array}{c}\mathbf{5 0 . ~ W r} \\
\text { Werk en } \\
\text { (re)integratie }\end{array}$ & $\begin{array}{c}\text { 51. Gt } \\
\text { Groothandel in } \\
\text { textiel- } \\
\text { goederen }\end{array}$ & $\begin{array}{c}\text { 52. Ms } \\
\text { Molenaars }\end{array}$ & $\begin{array}{c}\text { 53. Pd } \\
\text { Personeels- } \\
\text { diensten }\end{array}$ & $\begin{array}{c}\mathbf{5 4 . ~ Z v} \\
\text { Zeevisserij }\end{array}$ & $\begin{array}{c}\mathbf{5 5 .} \mathbf{Z b} \\
\text { Zwembaden }\end{array}$ & $\begin{array}{c}\mathbf{5 6 .} \mathbf{Z u} \\
\text { Zuivel- } \\
\text { industrie }\end{array}$ \\
\hline $\begin{array}{c}\mathbf{5 7 .} \mathbf{V b} \\
\text { Verzekerings- } \\
\text { bedrijf } \\
\text { binnendienst }\end{array}$ & $\begin{array}{c}\mathbf{5 8 .} \text { Vd } \\
\text { Verzekerings- } \\
\text { bedrijf } \\
\text { buitendienst }\end{array}$ & $\begin{array}{l}\text { 59. Ub } \\
\text { Uitgeverij- } \\
\text { bedrijf }\end{array}$ & $\begin{array}{l}\text { 60. Uv } \\
\text { Uitvaart- } \\
\text { branche }\end{array}$ & $\begin{array}{l}\text { 61. Td } \\
\text { Toneel en } \\
\text { dans }\end{array}$ & $\begin{array}{l}\text { 62. Rt } \\
\text { Regeling } \\
\text { tewerkstelling } \\
\text { niet-EU- } \\
\text { officieren } \\
\text { zeeschepen }\end{array}$ & $\begin{array}{l}\text { 63. Ra } \\
\text { Regeling } \\
\text { Arbeidsvoor- } \\
\text { ziening } \\
\text { Zeescheepvaart }\end{array}$ \\
\hline $\begin{array}{r}64 \\
\text { Rail } \\
\text { stru }\end{array}$ & $\begin{array}{r}65 \\
P \\
\text { vers }]\end{array}$ & $\begin{array}{l}\text { t- } \\
\text { iders }\end{array}$ & $\begin{array}{l}67 \\
\text { Off } \\
\text { Cat }\end{array}$ & $\begin{array}{r}68 \\
\text { Kalkz } \\
\text { /Cell } \\
\text { ind }\end{array}$ & $\begin{array}{l}\text { Kc } \\
\text { Isteen } \\
\text { eton- } \\
\text { rie }\end{array}$ & \\
\hline
\end{tabular}

31 Halsema (2015) vermeldt de eerste 54 bedrijfstakken met bcp-regelingen. Er hebben zich inmiddels onder meer de volgende wijzigingen voorgedaan: (a) vb Gb (nr. 13) is uitgebreid naar de bedrijfstak Zeevisserij (nr. 54), (b) vb Ba (nr. 15) was voorheen vb Waterbouw genaamd, (c) vb $\mathrm{Sm}$ (nr. 25), vb Wn (nr.36), vroegpensioenfonds $\mathrm{Br}$ (nr. 47) en vb Gt (nr. 51) zijn ondergebracht bij vb Dh (nr. 39), (d) vb Si (nr. 44) is ondergebracht bij vb Lb (nr.1), (e) vb Tv (nr. 28) is ondergebracht bij vb Mi (nr. 7) en (f) het vroegpensioenfonds $\mathrm{Tg}$ (nr. 48) verkeert in liquidatie en heeft de opgebouwde aanspraken en rechten op vroegpensioen (het gaat om ongeveer 44.000 polissen) per 1 juli 2017 ondergebracht bij verzekeraar Zwitserleven. 
In figuur 2 staan bij de nummers 1 tot en met 54 de bedrijfstakken weergegeven waarbinnen de bij de Directie Uitvoeringstaken Arbeidsvoorwaardenwetgeving aangemelde $\mathrm{bc}^{\prime} \mathrm{s}^{33}$ een bepaling met betrekking tot een deelnemingsverplichting in het aanpalende bpf vermelden. ${ }^{34}$ Binnen iedere (van die 54) te onderscheiden bedrijfstak(ken) vallen (naast het bpf en één of meerdere bc's) doorgaans ook één of meerdere bc's voor bedrijfstak-cao-fondsen (hierna: bcf's) ${ }^{35}$ aan te wijzen. $\mathrm{Na}$ algemeenverbindendverklaring (hierna: avv) van deze bcp-regelingen ${ }^{36}$ kan binnen iedere (van die 54) bedrijfstak(ken) worden gesproken van een materieelwettelijk systeem van bcp-regelingen. Het is niet de bedoeling van het complex van bcp-regelingen dat werknemers onder de bc van de ene bedrijfstak en onder het bpf van een andere bedrijfstak vallen. ${ }^{37}$ Artikel 4 Vrijstellingsbesluit Wet $\mathrm{Bpf}^{38}$ kan als een bevestiging daarvan worden gezien. Een bpf verleent namelijk op grond van dat artikel verplicht vrijstelling aan een werkgever indien (1) de algemeen verbindend verklaarde bepalingen van de bc niet op deze werkgever van toepassing zijn of (2) aan deze werkgever dispensatie is verleend van toepassing

32 Halsema (2015) vermeldt niet de bedrijfstakken $55 \mathrm{t} / \mathrm{m}$ 69. Het betreft bedrijfstakken waarbinnen weliswaar bc's bestaan waarvan bepalingen algemeen verbindend worden verklaard (hierna: avv), maar waar geen wettelijk verplichte deelneming in een bpf bestaat. Zie voor nr. 55 Zb (avv-bc van 27 april 2018 t/m 31 december 2018, Stcrt. 26 april 2018, nr. 1639) met een 'niet avv-pensioenbepaling' omtrent aansluiting bij bpf Rc (nr. 49); nr. 56 Zu (avv-bc van 13 mei 2017 t/m 31 maart 2018, Stcrt. 12 mei 2017, nr. 21112) met een 'niet avv-pensioenbepaling' omtrent aansluiting bij bpf Zu; nr. 57 Vb (avv-bc van 25 november 2017 t/m 31 december 2017, Stcrt. 24 november 2017, nr. 60163); nr. 58 Vd (avv-bc van 25 november 2017 t/m 31 december 2017, Stcrt. 24 november 2017, nr. 60169); nr. 59 Ub (avv-bc van 15 september 2016 t/m 28 februari 2017, Stcrt. 14 september 2016, nr. 39115); nr. 60 Uv (avv-bc van 1 juli 2016 t/m 31 december 2017, Stcrt. 22 juni 2016, nr. 26176); nr. 61 Td (avv-bc van 25 april 2017 t/m 24 april 2019, Stcrt. 24 april 2017, nr. 16752) met een 'niet avv-pensioenbepaling' omtrent aansluiting bij bpf Zw (nr. 38); nr. 62 Rt (avv-bc van 16 februari 2017 t/m 31 december 2017, Stcrt. 15 februari 2017, nr. 3715); nr. 63 Ra (avv-bc van 16 februari 2017 t/m 31 december 2017, Stcrt. 15 februari 2017, nr. 3707); nr. 64 Ri (avv-bc van 6 september 2012 t/m 28 december 2012, Stcrt. 5 september 2012, nr. 16470); nr. 65 Pv (avv-bc van 1 januari 2012 t/m 31 december 2013, Stcrt. 7 december 2011, nr. 20037); nr. 66 Os (avv-bc van 9 september 2016 t/m 31 december 2017, Stcrt. 8 september 2016, nr. 42187) met een 'niet avv-pensioenbepaling' omtrent aansluiting bij bpf Bw (nr. 29); nr. 67 Oc (avv-bc van 3 oktober 2017 t/m 30 juni 2019, Stcrt. 2 oktober 2017, nr. 50264); nr. 68 Kc (avv-bc van 10 augustus 2017 t/m 30 juni 2018), Stcrt. 9 augustus 2017, nr. 40500); nr. 69 Bk (avv-bc van 19 augustus 2011 t/m 31 december 2011, Stcrt. 18 augustus 2011, nr.13666).

33 Artikelen 1 t/m 3 Wet cao jo. artikel 4 Wet op de loonvorming (Stb. 1999, 30).

34 Figuur 2 is geïnspireerd op het 'periodiek systeem der elementen' zoals dat onder meer wordt gebruikt in de chemie.

35 Een bcf geldt ten behoeve van (één of meer bedrijfstakken of delen van) een bedrijfstak (artikel 1 lid 1 e.v. Besluit fondsen en spaarregelingen, Stb. 2017/341). Een bcf heeft bijvoorbeeld betrekking op scholing of vervroegde uittreding of een uitkering bij werkloosheid of arbeidsongeschiktheid en arbeidsomstandigheden. Asser/Heerma van Voss 7-V 2015/546 en 556.

36 Vanzelfsprekend op grond van enerzijds de Wet Bpf en anderzijds de Wet AVV.

37 NJ 2016/465 en PJ 2016/155 (Mt/Tussendiepen vh. Bam).

38 Besluit van 21 december 2000, houdende regels met betrekking tot de gevallen waarin en de voorwaarden waaronder een bedrijfstakpensioenfonds vrijstelling van de verplichte deelname aan een bedrijfstakpensioenfonds verleent, kan verlenen, intrekt en kan intrekken (Stb. 2000, 633). 
van de bc. ${ }^{39}$ De nummers 55 tot en met 69 in figuur 2 betreffen bedrijfstakken waarbinnen weliswaar bc's bestaan waarvan bepalingen algemeen verbindend worden verklaard, maar waar geen wettelijk verplichte deelneming in een bpf bestaat. ${ }^{40}$ Figuur 2 betreft een categoriaal systeem met een (in de loop der tijd aan te passen en te verfijnen) indeling van de te onderscheiden bedrijfstakken. ${ }^{41} \mathrm{Dit}$ categoriaal systeem is een nuttig raamwerk om de bcp-regelingen nader te analyseren. Via deze weg kan uiteindelijk tot een diagnostisch systeem (een rekenmodel) worden gekomen waarmee de toepasselijke werkingssfeer van bedrijfstakregelingen op een bedrijf (te weten de onderneming van een werkgever $)^{42}$ op basis van controleerbare variabelen kan worden vastgesteld (uitgerekend). ${ }^{43}$ Een dergelijk rekenmodel is mede gezien de geschetste risico's nuttig. Zulks temeer omdat

39 De vb van een bpf komt op gezamenlijke aanvraag van 'het georganiseerde bedrijfsleven in de bedrijfstak' tot stand. Bij de beoordeling van de representativiteit wordt zowel gekeken naar de werkgevers- als naar de werknemerspartijen. Daarentegen kan een avv-verzoek van bepalingen van een bc worden ingediend door één of meer werkgevers of één of meer verenigingen van werkgevers of werknemers. Artikel 1 onder f en artikel 2 lid 1 Wet Bpf 2000. Artikel 1 Pensioenwet (Pw). Toetsingskader-bpf, par. 3.1.a. Asser/Lutjens 7-XI 2016/284.

40 De wettelijk bindende normerende kracht van de bc met toepasselijkheidverklaring van een pensioenregeling geldt wel voor die leden van de contracterende partijen die een arbeidsverhouding zijn aangegaan of kunnen aangaan, waarvan de inhoud door de bc wordt genormeerd, dus die onder de in de cao beschreven werkingssfeer (het toepassingsgebied) van de cao vallen (artikel 9 Wet cao). Asser/Heerma van Voss 7-V 2015/556.

41 Deze bijdrage ziet niet op pensioenregelingen op grond van (a) de Wet privatisering ABP, (b) de Wet verplichte beroepspensioenregeling, (c) de Kaderwet militaire pensioenen, (d) de Algemene pensioenwet politieke ambtsdragers en (e) de Wet op het notarisambt. Lutjens 2017.

42 Van Dale Online: bedrijf: een onderneming die zich bezighoudt met het maken en/of verhandelen van bepaalde goederen en/of het leveren van bepaalde diensten. Het begrip 'onderneming' heeft noch binnen het arbeidsrecht noch binnen het ondernemingsrecht een vastomlijnde betekenis. Zie de conclusie van A-G De Bock 27 mei 2016, ECLI:NL:PHR:2016:449, 3.12 en 3.13.

43 Voor onderworpenheid aan de rechten en verplichtingen van bcp-regelingen dient een werkgever eerst en vooral onder de werkingssfeer van die regelingen te vallen. Het antwoord op de vraag of men daaronder valt, wordt gegeven door uitleg van de werkingssfeerbepalingen. Asser/Heerma van Voss 7-V 2015/573; Jacobs 2017, par. 5.3.3. De uitleg van (begrippen in) werkingssfeerbepalingen in bcp-regelingen (betreft een rechtsoordeel over materiële wetgeving en) vindt plaats met toepassing van de zogenoemde 'cao-norm'. HR 20 februari 2004, ECLI:NL:HR:2004:AO1427, NJ 2005/493 (DSM/Fox). Asser/Lutjens 7-XI 2016/161 en 303; Asser/Heerma van Voss 7-V 2015/550 e.v.; H.L. Bakels e.a., Schets Nederlandse arbeidsrecht, 2017, par. 5.3.1. Bij de uitleg van werkingssfeerbepalingen van bcp-regelingen kan mede betekenis worden toegekend aan de werkingssfeer van andere bcp-regelingen. De verschillende besluiten van de minister tot verplichtstelling van bcp-regelingen zijn zo geformuleerd dat een overlapping van de werkingssferen zo veel mogelijk wordt voorkomen. NJ 2011/258 (Mt/Bam). Toetsingskader-avv, par. 6.2 sub 1 en Toetsingskader-bpf par. 2. 
werkgevers en werknemers automatisch ${ }^{44}$ onder (of buiten) de werkingssfeer van bcp-regelingen vallen. ${ }^{45}$ Een incidentele bedrijfstakactiviteit van een werkgever ${ }^{46}$ of een werknemer ${ }^{47}$ leidt niet tot toepasselijkheid van bcp-regelingen. De werkingssfeer van bcp-regelingen zal echter wel toepasselijk op een werkgever kunnen worden indien zijn werknemers structureel ('steeds terugkerend') en stelselmatig ('volgens een vast patroon') bij bedrijfstakwerkzaamheden betrokken zijn. Een werknemer is doorgaans volgens een in de gesloten arbeidsovereenkomst neergelegd terugkerend vast patroon voor de werkgever werkzaam. Artikel 7:655 lid 1 van het Burgerlijk Wetboek (BW) vermeldt dat een werkgever schriftelijk aan de werknemer, naast zijn functie of de aard van zijn arbeid, de gebruikelijke arbeidsduur per dag of per week en het loon moet laten weten. Hierna zal blijken dat deze informatie van belang is voor de beoordeling van de toepasselijke werkingssfeer van bcp-regelingen. ${ }^{48}$ Het ligt op de weg van een werkgever te onderzoeken of bcp-regelingen op hem van toepassing zijn, dit in het bevestigende geval $^{49}$ aan zijn werknemers kenbaar te maken en werknemersgegevens aan (bij-

44 De rechtsgevolgen van bcp-regelingen voor een werkgever en zijn werknemers vloeien rechtstreeks uit de wet voort. Verplicht gestelde bcp-regelingen zijn volgens vaste rechtspraak objectief recht in de zin van artikel 79 Wet RO. Asser Procesrecht/Korthals Altes \& Groen 7 2015/174. De avv van bepalingen van een bc heeft tot gevolg dat die bepalingen bindend zijn ten opzichte van de werkgever die valt onder de (in die bepalingen beschreven) werkingssfeer (het toepassingsgebied) van de bc, ongeacht of laatstgenoemde partij is bij de betreffende bc. Asser/Heerma van Voss 7-V 2015/533. De vb is bindend ten opzichte van de werkgever die valt onder haar werkingssfeer (het toepassingsgebied), ongeacht of laatstgenoemde lid is van een werkgeversvereniging op wier verzoek de vb is aangevraagd. Zolang de vb van een bpf duurt zijn de deelnemers en, voor zover het werknemers betreft, hun werkgevers verplicht de statuten en reglementen en de daarop gebaseerde besluiten van het bestuur van het bpf na te leven. Artikel 3 lid 1 jo. artikelen 4 tot en met 26 Wet Bpf 2000. Deze nalevingsplicht geldt ook na beëindiging van de vb voor de periode dat deze duurde. Asser/Lutjens 7-XI 2016/287.

45 Er vallen vier aspecten van de werkingssfeer te onderscheiden. Het betreft de werkingssfeer van een bedrijfstakregeling ten aanzien van (a) de onderneming: de 'horizontale werkingssfeer', (b) groepen van werknemers: de 'verticale werkingssfeer', (c) het (eventuele deel van het) land waarvoor deze geldt: de 'territoriale werkingssfeer', en (d) de duur waarvoor deze geldt: de 'temporele of periodieke werkingssfeer'. Jacobs 2017, par. 5.4. Deze bijdrage heeft betrekking op de horizontale werkingssfeer.

46 Een werkgever 'pleegt' bedrijfstakwerkzaamheden te verrichten, in de betekenis dat dit 'geregeld' geschiedt. Rb. Den Haag 18 december 1967, ECLI:NL:RBSGR:1967:AB5302, NJ 1969/119 (Stichting Pensioenfonds voor de Vervoer- en Havenbedrijven/Haven- en Controlebedrijf 'Bremah'). Asser/Lutjens 7-XI 2016/308.

47 Indien een werknemer slechts incidenteel bedrijfstakwerkzaamheden verricht, zijn de bcp-regelingen niet op hem van toepassing als de onderneming van zijn werkgever verder niet onder de werkingssfeer van die regelingen valt. HR 1 november 1957, NJ 1960/173 (Bpf Bouwnijverheid/N.V. Intercommunale Waterleiding Gebied Leeuwarden). Jacobs 2017, par. 5.4.1.

48 Deze informatie is ook van belang voor de berekening van verschuldigde pensioenpremies en cao-bijdragen aan bcp-fondsen, doorgaans een percentage van de loonsom (de zogenoemde 'doorsneepremie').

49 In aanvulling op artikel 7:655 lid 1 sub j BW is in artikel 7 Pw voor de werkgever de verplichting opgenomen om de werknemer schriftelijk te informeren of hij de werknemer al dan niet een aanbod voor een pensioenovereenkomst zal gaan doen. Een verplichte deelneming in een bpf wordt met een dergelijke pensioenovereenkomst gelijk gesteld (artikel 2 lid $2 \mathrm{Pw}$ ). Op de werkgever rust derhalve de verplichting de werknemer schriftelijk te informeren indien deze verplicht gaat deelnemen in een bpf. Asser/Lutjens 7-XI 2016/124 en 132. 
voorbeeld de uitvoeringsorganisatie van) de bcp-fondsen te verstrekken. ${ }^{50}$ Zoals gezegd, is het de vraag op welke logische wijze de toepasselijkheid van bcp-regelingen kan worden beoordeeld en in het gunstigste geval kan worden berekend. Ter beantwoording van die vraag wordt hierna ingegaan op de systematiek van de werkingssfeer van de oudste bedrijfstakken, te weten de Landbouw (Lb), de Metalektro (Me) en de Metaal en Techniek (Mt). ${ }^{51}$ Indien er patronen en relaties kunnen worden aangewezen binnen en tussen deze bedrijfstakken en daaraan variabelen (en dus getallen) kunnen worden gekoppeld, dan kan tot een formule worden gekomen voor de berekening van de op een werkgever toepasselijke werkingssfeer van bcp-regelingen.

\section{De variabelen binnen de Landbouw, de Metalektro en de Metaal en Techniek}

Het zal blijken dat weliswaar naar de aard (op enkele te noemen uitzonderingen na) de kwalitatieve werkingssfeercriteria (omtrent de aard van de arbeid) binnen deze drie bedrijfstakken verschillen, maar dat de relevante kwantitatieve werkingssfeercriteria (omtrent de omvang van de arbeid) overeenkomen. Dit is belangrijk, omdat mede op grond daarvan (op basis van variabelen) tot een rekenmodel voor de beoordeling van de werkingssfeer van bcp-regelingen kan worden gekomen.

\subsection{De bcp-regelingen zijn volgens hetzelfde patroon samengesteld}

In de bijlage ${ }^{52}$ valt te zien dat de bcp-regelingen binnen de te onderscheiden bedrijfstakken Lb, Me en Mt volgens hetzelfde patroon zijn samengesteld. Binnen deze bedrijfstakken vallen steeds een bpf, meerdere bc's en één of meerdere bcf's aan te wijzen. ${ }^{53}$ Binnen de bedrijfstak $L b$ vallen takken van bedrijf te onderscheiden $^{54}$ zoals (1) de Bedrijfsverzorgingsdiensten, ${ }^{55}$ (2) de Bloembollengroothandel, ${ }^{56}$ (3) de Bos- en Natuuronderneming, ${ }^{57}$ (4) de Land- en tuinbouwwerktuigen exploiterende onderneming, ${ }^{58}$ (5) Cultuurtechnische Werken, ${ }^{59}$ (6) het Hove-

50 Gerechtshof Amsterdam 11 augustus 2015, ECLI:NL:GHAMS:2015:3250, PJ 2015/141 (Vervoer/x); Rb. Midden-Nederland 5 oktober 2015, ECLI:NL:RBMNE:2015:7254, PJ 2015/174 (Schoonmaak/x); Gerechtshof Den Haag 14 juli 2015, ECLI:NL:GHDHA:2015:1871, PJ 2015/140 (Landbouw/x).

51 Halsema 2015, p. 1 t/m 368.

52 De in noot 56 e.v. weergegeven afkortingen worden verduidelijkt in de bijlage.

53 Het is steeds van belang te bezien of bepalingen van een cao door de minister algemeen verbindend zijn verklaard.

$54 \mathrm{Vb}$ Lb onder C1 tot en met 14.

55 Deze tak blijft, gezien het uitleenkarakter, in deze bijdrage verder buiten beschouwing.

56 Bc LbBg 2016/2018, artikel 01.01 lid 1 sub a.

57 Bc LbBn 2016/2017, artikel 1.2.

58 Bc LbLe 2016/2017, artikel 2 lid 1 sub a en b.

59 Cultuurtechnische Werken valt bij vb Lb onder de Land- en tuinbouwwerktuigen exploiterende onderneming. 
niersbedrijf, ${ }^{60}$ (7) de Glastuinbouw, ${ }^{61}$ (8) de Open Teelten, ${ }^{62}$ (9) de Dierhouderij, ${ }^{63}$ (10) de Paddenstoelenteelt, ${ }^{64}$ (11) de Groenvoederdrogerij, ${ }^{65}$ (12) de Tuinbouwzaadteelt, ${ }^{66}$ (13) de Rundveeverbetering, ${ }^{67}$ (14) de Varkensverbeteringsorganisatie $^{68}$ en (15) de Groenten- en fruitverwerkende industrie. ${ }^{69}$

Binnen de bedrijfstak $M t$ vallen takken van bedrijf te onderscheiden ${ }^{70}$ zoals (1) het Metaalbewerkingsbedrijf, ${ }^{71}$ (2) het Technisch Installatiebedrijf, ${ }^{72}$ (3) de Goud- en Zilvernijverheid, ${ }^{73}$ (4) het Carrosseriebedrijf, ${ }^{74}$ (5) het Isolatiebedrijf, ${ }^{75}$ (6) de Tankstations en Wasbedrijven, ${ }^{76}$ (7) het Motorvoertuigenbedrijf en Tweewielerbedrijf ${ }^{77}$ en (8) de Zeilmakerijen, Dekkledenvervaardiging, Dekkledenverhuur, Scheepstuigerijen en de Scheepsbenodigdhedenhandel. ${ }^{78}$ Binnen deze takken van bedrijf vallen doorgaans weer sub-takken te onderscheiden. In paragraaf 3.4 wordt ingegaan op de relatie tussen de bedrijfstak Me en de bedrijfstak Mt op het gebied van het Metaalbewerkingsbedrijf en onderdelen van het Technisch Installatiebedrijf.

De bcp-regelingen in de Lb, Me en Mt zijn niet alleen volgens hetzelfde patroon samengesteld, maar vermelden tevens in hun kwalitatieve werkingssfeerbepalingen een omschrijving van de werkzaamheden die daaronder vallen.

\subsection{De begrippen werknemer, werkgever en onderneming}

De bcp-regelingen in de Lb, Me en Mt kwalificeren een werknemer als de natuurlijke persoon die op basis van een arbeidsovereenkomst als bedoeld in arti-

60 Bc LbHb 2016/2018, artikel 2 lid 1 sub a tot en met $f$.

61 Bc LbGt 2016/2018, artikel 1 lid 1 sub a.

62 Bc LbOt 2016/2017, artikel 1.a.

63 Bc LbDh 2014/2017, artikel 1 lid 1 sub a.

64 Bc LbP 2003/2004, artikel 1.a.

65 Bc LbGd 2016/2018, artikel 1.1.

66 Bc LbTb 2016/2017, artikel 1.1.

67 Bc LbRv 2009, artikel 1.1.

68 Bc LbVv 2013, artikel 4.1.

69 Bc LbGfi 2016, artikel 1 onder b sub 2 (a en b).

70 Vb Mt, artikel 20: 'Onder de "Metaal en Techniek" in deze Verplichtstellingsbeschikking wordt verstaan de takken van bedrijf als hiervoor omschreven in artikel $1 \mathrm{t} / \mathrm{m}$ 17.' Idem bc Avim 2014/2018, artikel 1 sub D en bc Sfm 2014/2018, artikel 1 sub D. Vgl. voor de werkzaamheden die onder MtMb vallen bc MtMb 2016/2017, artikel 77. Vgl. voor de werkzaamheden die onder MtTi vallen bc MtTi 2016/2017, artikel 77. Met betrekking tot vb Mt, artikelen 8 en 15 geldt slechts een deelnemingsverplichting in bpf Mt.

$71 \mathrm{Vb}$ Mt, artikelen $1 \mathrm{t} / \mathrm{m}$ 7, artikel 12 (deze werkzaamheden kunnen zowel onder het MtMb als het MtTi vallen) en artikel 17.

$72 \mathrm{Vb}$ Mt, artikelen 9 en 12 (deze werkzaamheden kunnen zowel onder het MtTi als het MtMb vallen).

$73 \mathrm{Vb}$ Mt, artikel 13.

74 Vb Mt, artikel 10.

75 Vb Mt, artikel 14.

76 Vb Mt, artikel 11.

$77 \mathrm{Vb} \mathrm{Mt}$, artikelen 11 en 13A.

78 Vb Mt, artikel 16. 
kel 7:610 BW in dienst is van de werkgever. Deelneming in het bpf ${ }^{79}$ en toepassing van de relevante te onderscheiden bc's binnen de bedrijfstak zijn verplicht gesteld ${ }^{80}$ voor de werknemers in dienst van een werkgever binnen de betreffende bedrijfstak. ${ }^{81}$ De bcp-regelingen in de Lb, ${ }^{82} \mathrm{Me}^{83}$ en $\mathrm{Mt}^{84}$ kwalificeren een werkgever als de natuurlijke persoon, een personenvennootschap of een rechtspersoon die een onderneming uitoefent. Die onderneming kan de juridische eenheid of een onderdeel daarvan betreffen. ${ }^{85}$ Met betrekking tot het begrip 'onderneming' in vb Lb 1949 oordeelt de Hoge Raad op 12 maart 1954 als volgt. ${ }^{86}$

'dat van een onderneming als bedoeld in de zoeven genoemde beschikking slechts sprake zou kunnen zijn, indien een "onderneming” met een juridische eenheid samenvalt, in de bewoordingen dier beschikking geen steun vindt en met haar strekking niet wel verenigbaar is'.

79 Tenzij de in een vb vermelde leeftijdsgrens (bijvoorbeeld de pensioengerechtigde leeftijd van 67 jaar of bijvoorbeeld 21 jaar) al dan niet is bereikt.

80 Hierbij dient natuurlijk wel acht te worden geslagen op het al dan niet avv zijn van bepalingen van een bc.

81 Vgl. voor de bedrijfstak Landbouw vb Lb, onder A; bc LbOt 2016/2017, artikel 3 lid 2; bc LbGt 2016/2018, artikel 3 lid 2; bc LbGfi 2016, artikel 1 onder b sub 2 (d); bc LbGb 2016/2018, artikel 01.02 lid 1 sub b; bc LbHb 2016/2018, artikel 2 lid 1 sub h; bc LbLe 2016/2017, artikel 2 lid 1 sub d; en bc LbDh 2014/2017, artikelen 1 en 2 lid 2. Vgl. voor de bedrijfstak Metalektro vb Me, artikel 1 lid 2; bc Me 2016/2018, artikelen 1.1.1 en 1.1.2; bc MeAo 2016/2018, artikelen 1.1 en 1.2; en bc MeHp 2016/2018, artikel 1.1.1. Vgl. voor de bedrijfstak Metaal en Techniek vb Mt, artikel 23; bc Avim 2014/2018, artikel 1 sub c; bc Sfm 2014/2018, artikel 1 sub c; bc MtMb 2017/2019, artikel 2; en bc MtTi 2017/2019, artikel 2.

$82 \mathrm{Vb} \mathrm{Lb}$, onder B.1.a en onder B.1.c.

83 Vb Me, artikel 1; bc Me 2016/2018, artikelen 1.1.1 en 1.1.2; bc MeAo 2016/2018, artikelen 1.1 en 1.2; en bc MeHp 2016/2018, artikel 1.1.2.

84 Vb Mt, artikel 21; bc Avim 2014/2018, artikel 1 sub b; bc Sfm 2014/2018, artikel 1 sub b; bc MtMb 2017/2019, artikel 1; en bc MtTi 2017/2019, artikel 1.

85 De Me-regelingen kwalificeren blijkens de definitie van het begrip 'werkgever' slechts de natuurlijke of rechtspersoon als werkgever, terwijl de Mt-regelingen daarnaast tevens een personenvennootschap en een nevenvestiging als werkgever kwalificeren. Moet nu op grond hiervan worden aangenomen dat een personenvennootschap en een nevenvestiging, ongeacht de werkzaamheden van de werknemers en ongeacht het aantal arbeidsuren per week, nimmer tot de bedrijfstak Me kan behoren? Dit lijkt geen juiste uitleg. Immers wordt een personenvennootschap gevormd door twee of meer natuurlijke personen en/of rechtspersonen gezamenlijk en zal een nevenvestiging ook te herleiden zijn tot een natuurlijke persoon en/of een rechtspersoon. Een juiste uitleg van het begrip werkgever in de Me-regelingen lijkt dat dit begrip tevens doelt op de natuurlijke personen en/of rechtspersonen die een personenvennootschap vormen en/of een vestiging hebben. De natuurlijke personen en/of rechtspersonen zijn (juridisch) aansprakelijk (ook wat betreft een vestiging) voor de nakoming van de verplichtingen die uit de Me-regelingen voortvloeien. Deze uitleg spoort ook met het begrip 'werkgever in een onderneming in de Metalektro', dat eveneens in de Me-regelingen staat vermeld (vgl. vb Me, artikel 2 lid 1). Deze 'onderneming' zal dan een personenvennootschap of een vestiging kunnen betreffen. Ook lijkt een andere uitleg in strijd met het materieel-wettelijk systeem zoals dat wordt gevormd door de Mten Me-regelingen en (in strijd met regeringsbeleid) het ontgaan van deze bcp-regelingen (en daarmee concurrentie op arbeidsvoorwaarden) in de hand te werken. Toetsingskader-bpf onder 1 en Toetsingskader-avv onder 1.

86 Vb Lb, Stcrt. 1949, nr. 104, p. 5. HR 12 maart 1954, ECLI:NL:HR:1954:153, NJ 1954/254 (Oud Schoonebeeker Turfstrooiselfabriek en Veenderij A. Veldkamp/Lb). 
Anders dan in de vb Lb 2017 is de tekst 'uitsluitend of in hoofdzaak' in de vb Lb 1949 nog niet uitgewerkt. De rechtbank overweegt in het in cassatie in stand gelaten vonnis dat de woorden 'uitsluitend of in hoofdzaak' niet slaan op de ondernemer of exploitant van één of meer ondernemingen, maar op elke onderneming die door de ondernemer wordt geëxploiteerd. ${ }^{87}$ De Lb-regelingen vermelden inmiddels uitdrukkelijk dat deze eveneens betrekking kunnen hebben op een 'onderdeel' van een onderneming waarin bedrijfstakactiviteiten binnen de Lb worden verricht. ${ }^{88}$ Hierbij kan worden gedacht aan een afdeling of een vestiging. ${ }^{89}$ Kort samengevat vermelden de drie bcp-regelingen begrippen zoals 'werknemer', 'werkgever (de natuurlijke persoon, een personenvennootschap of een rechtspersoon die een onderneming uitoefent' en '(onderdeel van een) onderneming'.

\subsection{De werkzaamheden en de irrelevante economische functie}

De werkzaamheden van de werknemers moeten aan de te onderscheiden bcp-regelingen kunnen worden toegerekend. De Hoge Raad oordeelt op 12 maart 1954 dat vb Lb 1949 'geen grond geeft voor de opvatting dat het motief, waarom de veenderij [behorende tot de bedrijfstak Lb; $\mathrm{MH}$ ] wordt uitgeoefend, beslissend is'. De rechtbank overweegt als volgt in het vergeefs in cassatie bestreden vonnis. ${ }^{90}$

'dat de motieven, welke de [rechtspersoon; $\mathrm{MH}$ ] er toe leiden deze [bedrijfstakonderneming; $\mathrm{MH}$ ] als onderdeel van haar totale activiteit op economisch gebied te exploiteren, in deze geen rol kunnen spelen, daar over enig motief in de beschikking niet wordt gesproken noch daarnaar wordt verwezen'.

De Hoge Raad oordeelt op 26 oktober 2007 in vergelijkbare zin. ${ }^{91}$ De Hoge Raad acht van belang dat de werknemers van de werkgever in de bc Tuinbouw vermelde kwekersactiviteiten verrichten en niet zozeer van belang dat de geteelde (pot)planten uiteindelijk door de werkgever worden verkocht. ${ }^{92}$ De Lb-regelingen vermelden niet dat de 'economische functie van de werkzaamheden' van de werknemers of de 'economische functie van de onderneming' van de werkgever relevant is voor de beoordeling van de werkingssfeer. De relevante werkingssfeerbepalingen van de Mt-regelingen (waarmee de Me-regelingen verband houden) vermelden uitdrukkelijk dat (onder meer) de 'economische functie van de onderneming' van de werkgever voor de beoordeling van de toepasselijkheid van de werkingssfeer irrelevant is (vb Mt; cursivering $\mathrm{MH}$ ).

87 NJ 1954/254 (Oud Schoonebeeker Turfstrooiselfabriek en Veenderij A. Veldkamp/Lb), r.o. 19.

$88 \mathrm{Vb}$ Lb, onder B.1.b.

89 Vgl. met betrekking tot het begrip onderdeel van een onderneming in een andere bedrijfstak HR 23 september 2016, ECLI:NL:HR:2016:2171, r.o. 3.4.3, NJ 2016/427 (x/Fnv): 'Uit de tekst en systematiek van de CAO voor de Gemaksvoedingindustrie volgt dat ook indien sprake is van samenwerking in een groep of concern door meerdere rechtspersonen zoals voor dit geval door het hof is vastgesteld, voor iedere rechtspersoon afzonderlijk dient te worden bezien of de cao van toepassing is.'

90 NJ 1954/254 (Oud Schoonebeeker Turfstrooiselfabriek en Veenderij A. Veldkamp/Lb), r.o. 21.

91 HR 26 oktober 2007, ECLI:NL:HR:2007:BA6760, r.o. 3.4, JAR 2007/286.

92 De bc Tuinbouw heeft op 1 april 2001 opgehouden te gelden. Per die datum treden twee nieuwe bc's voor de Tuinbouw in werking, te weten de bc Glastuinbouw en de bc Open teelten. 
'De deelneming in het Pensioenfonds Metaal en Techniek is verplicht gesteld voor: de werknemers in de zin van de Pensioenwet (Wet van 7 december 2006, Staatsblad 2006, 705); directeuren-grootaandeelhouder in de zin van de Pensioenwet (Wet van 7 december 2006, Staatsblad 2006, 705), met uitzondering van die directeuren-grootaandeelhouder op wie de situatie zoals genoemd in 25 sub 5 en sub 7 hieronder van toepassing is, die werkzaam zijn in ondernemingen, in welke, ongeacht de economische functie, uitsluitend of in hoofdzaak één of meer van de hierna onder sub 1 t/m 17 genoemde werkzaamheden worden uitgeoefend'.

Gesteld kan worden dat noch de 'economische functie van de werkzaamheden' van de werknemers, noch de 'economische functie van de onderneming' van de werkgever voor de beoordeling van de toepasselijkheid van de werkingssfeer van de in deze bijdrage behandelde bcp-regelingen relevant is.

\subsection{Het hiërarchische systematische verband tussen de bcp-regelingen}

Dat de Me-regelingen en de Mt-regelingen met elkaar verband houden, volgt zowel uit de tekst van die regelingen als uit het hiërarchische systematische verband tussen de te onderscheiden bcp-regelingen. De werkingssfeer van een later tot stand gekomen regeling kan naar de aard niet werkzaamheden (c.q. een onderneming) insluiten die al door de werkingssfeer van een eerdere regeling worden (c.q. wordt) ingesloten. ${ }^{93}$ Daarom kan tussen de Lb-regelingen en de daarna tot stand gekomen Me-regelingen en Mt-regelingen worden gesproken van een materieelwettelijk systeem van insluiten en uitsluiten op het gebied van onder de werkingssfeer vallende werkzaamheden c.q. ondernemingen. Dit wordt bevestigd door de Mt-regelingen en de Me-regelingen. Ten eerste nu deze als volgt uitdrukkelijk naar elkaar verwijzen: ${ }^{94}$

a De Mt-regelingen vermelden dat niet tot de bedrijfstak Mt worden gerekend ondernemingen die onder de werkingssfeer van de Me-regelingen ressorteren. ${ }^{95}$

b De Me-regelingen vermelden dat niet tot de bedrijfstak Me worden gerekend ondernemingen die daar weliswaar (naar de aard op grond van artikel 2 lid 7 $\mathrm{vb} \mathrm{Me}$ ) onder vallen, maar die met goedkeuring van de in de bedrijfstak $\mathrm{Me}$

93 P.J. Boon, Regelgeving in Nederland, 2005, p. 21. Toetsingskader-avv, par. 6.2 en Toetsingskader-bpf, par. 2.

94 De systematiek van bcp-regelingen impliceert dat naarmate (werkingssfeerbepalingen in) bcpregelingen een hiërarchisch lagere rang hebben ('de jongere regeling'), de kans groter wordt dat afstemming van hun werkingssfeer met één of meer (werkingssfeerbepalingen in) bcp-regelingen met een hiërarchisch hogere rang ('de oudere regeling') noodzakelijk is.

95 Vb Mt, artikel 24 met betrekking tot vb Me en bc Otib 2015/2019, artikel 6 lid 6 e.v. en bc Oom 2015/2019, artikel 6 lid 4 sub e e.v. Vb Mt 1964 vermeldt (net als vb Mt 2015) een bepaling ter voorkoming van samenloop met vb Me (Stcrt. 31 december 1963, 252): 'dat niet tot de metaalnijverheid [de oude benaming voor $\mathrm{Mt}$; $\mathrm{MH}$ ] worden gerekend ondernemingen welke onder de werkingssfeer van het bedrijfspensioenfonds voor de Metaalindustrie [de oude benaming voor Me; $\mathrm{MH}]$ ressorteren'. 
bevoegde instantie onder de werkingssfeer van de bedrijfstak Mt ressorteren. ${ }^{96}$

Ten tweede vermelden de Mt-regelingen en de Me-regelingen twee varianten van spiegelbeeldige bepalingen ter voorkoming van samenlopende werkingssferen. Het betreft (a) één variant waarbij (gezien de aard van de werkzaamheden) het aantal overeengekomen arbeidsuren per week niet van belang is, en (b) één variant waarbij zowel de aard van de werkzaamheden als het aantal overeengekomen arbeidsuren per week wel van belang is:

a De Me-regelingen vermelden dat daar (naar de aard, ongeacht het aantal arbeidsuren per week) ondernemingen onder vallen waarin uitsluitend of in hoofdzaak het bedrijf wordt uitgeoefend van het walsen van staal en/of het ijzer- en staalgietersbedrijf en/of het ontwerpen, ontwikkelen, vervaardigen en/of herstellen van vliegtuigen en/of liften en/of (kortweg) het hoogovenbedrijf. ${ }^{97}$ De Mt-regelingen vermelden (nagenoeg) ${ }^{98}$ spiegelbeeldige bepalingen ter voorkoming van samenlopende werkingssferen.

b De Me-regelingen en de Mt-regelingen vermelden op het gebied van het Metaalbewerkingsbedrijf en onderdelen van het Technisch Installatiebedrijf eveneens spiegelbeeldige samenloopbepalingen. Indien binnen een onderneming (die kwalificeert als werkgever in het Metaalbewerkingsbedrijf dan wel als werkgever in het Technisch Installatiebedrijf) bijvoorbeeld gedurende ten minste 1.200 uur per week door bij die onderneming in dienst zijnde werknemers werkzaamheden worden verricht, dan behoort een dergelijke onderneming tot de bedrijfstak Me. Worden er binnen een dergelijke onderneming minder dan 1.200 uur per week door bij die onderneming in dienst zijnde

$96 \mathrm{Vb}$ Me, artikelen 6 e.v. met betrekking tot vb Mt en bc Me 2016/2018, bijlage a, artikel 4, bc MeAo 2016/2018, bijlage a, artikel 4 en bc MeHp 2016/2018, bijlage a, artikel 5.

97 Vb Me, artikel 2 lid 7, bc Me 2016/2018, bijlage A, artikel 3, bc MeAo 2016/2018, bijlage A, artikel 3 en bc MeHp 2016/2018, bijlage A, artikel 4.

98 Deze bepalingen vermelden dat, ongeacht het aantal arbeidsuren, niet tot de bedrijfstak Mt behoren ondernemingen waarin uitsluitend of in hoofdzaak sprake is van het walsen van staal, het ijzer- en staalgietersbedrijf, het vervaardigen en/of herstellen van vliegtuigen en/of het vervaardigen en/of herstellen van liften (vb Mt, artikel 18.h; bc Avim 2014/2018, artikel 1 sub D onder 22; bc Sfm 2014/2018, artikel 1 sub D onder 21; en bc MtMb, artikel 77 lid 1 sub 1). Hoewel 'het ontwerpen, ontwikkelen' van zowel vliegtuigen als liften niet, en het 'vervaardigen en/of herstellen van' zowel vliegtuigen als liften wel door de tekst van de Mt-regelingen wordt uitgesloten van de werkingssfeer van deze regelingen, moet het ervoor worden gehouden dat 'het ontwerpen, ontwikkelen' van zowel vliegtuigen als liften eveneens wordt uitgesloten van de werkingssfeer van de Mt-regelingen. Zulks eenvoudigweg omdat deze werkzaamheden worden ingesloten door de werkingssfeer van de Me-regelingen, en de Mt-regelingen vermelden dat niet tot de bedrijfstak Mt worden gerekend ondernemingen die onder de werkingssfeer van de Me-regelingen ressorteren. Eenzelfde gedachtegang zal gelden voor 'het hoogovenbedrijf met inbegrip van zijn nevenbedrijven', dat weliswaar niet letterlijk door de tekst van de Mt-regelingen wordt uitgesloten, maar wel letterlijk door de tekst van de Me-regelingen wordt ingesloten. 
werknemers werkzaamheden verricht, dan behoort een dergelijke onderneming tot de bedrijfstak $\mathrm{Mt}^{99}$

Zowel de in kwalitatieve werkingssfeerbepalingen beschreven werkzaamheden van de werknemers als het hiërarchische systematische verband tussen de te onderscheiden bcp-regelingen maken dat werkzaamheden van werknemers aan de te onderscheiden bcp-regelingen kunnen worden toegerekend.

\subsection{Uitsluitend of in hoofdzaak; het 'betrokken bij'-criterium}

De bcp-regelingen vermelden als kwantitatief werkingssfeercriterium de woorden 'uitsluitend of in hoofdzaak'. ${ }^{100}$ Voor de uitleg van dat 'uitsluitend of in hoofdzaak'-criterium dient acht te worden geslagen op de uitwerking daarvan in deze bcp-regelingen. De Lb-regelingen vermelden het volgende (vb Lb, onder B.2): ${ }^{101}$

\section{'B Werkgever:}

1.a. Degene die een onderneming uitoefent waarvan de bedrijfsactiviteiten uitsluitend of in hoofdzaak bestaan uit activiteiten zoals onder C 1 tot en met 14 vermeld.

99 Vb Me artikel 2 lid 6 onder a, b en c; Bc Me 2016/2018, bijlage a, artikel 2 onder a, b en c; Bc MeAo 2016/2018, bijlage a, artikel 2 onder a, b en c; Bc MeHp 2016/2018, bijlage a, artikel 3 onder a, b en c. Vgl. vb Mt. Het betreft het metaalbewerkingsbedrijf (artikel 1), het elektrotechnisch wikkelbedrijf, het elektrotechnisch paneelbouwbedrijf en het elektrotechnisch reparatiebedrijf (artikel 9.2.a t/m c). Artikel 9.1.a vb Mt voorkomt de samenloop met het elektrotechnisch scheepsinstallatiebedrijf (binnen de Me-regelingen). Vgl. vb Mt, artikel 18; bc Avim 2014/2018, artikel 1 sub d onder 15 e.v. m.b.t. dezelfde takken van bedrijf; bc Sfm 2014/2018, artikel 1 sub d onder 14 e.v.; bc MtMb 2017/2019, artikel 77 lid 1 sub e e.v.; en bc MtTi 2017/2019, artikel 77 lid 3 e.v. Vgl. tevens vb Me, artikel2 lid 9 e.v.; bc Me 2016/2018, bijlage a, artikel 5 e.v.; bc MeAo 2016/2018, bijlage a, artikel 5 e.v. (er lijkt per abuis 'Metaalbewerkingsbedrijf' in plaats van Metaal en Techniek te staan); en bc MeHp 2016/2018, bijlage a, artikel 6 e.v.

100 De betekenis van uitsluitend in Van Dale is 'met uitsluiting van iets anders, enkel en alleen' en 'waarbij anderen uitgesloten zijn', zodat het zal gaan om de gevallen waarbij de (overeengekomen arbeidsuren van de) werknemers volledig (100\%) betrokken zijn bij werkzaamheden zoals uitgeoefend in een bedrijfstak. De betekenis van in hoofdzaak in Van Dale is '(de) belangrijkste (...) zaak' en het tegenovergestelde van 'bijzaak', oftewel dient de hoofdzaak te worden onderscheiden van de bijzaak.

101 Vb Lb, onder B; Bc LbOt 2016/2017, artikel 1 jo. 3 lid 1; Bc LbGt 2016/2018, artikel 1 jo. 3 lid 1; Bc LbGfi 2016, artikel 1 onder b sub 1; Bc LbGb 2016/2018, artikel 01.01 jo. 01.02 lid 1 sub a; Bc LbHb 2016/2018, artikelen 1 en 2 lid 1 sub g onder 1 tot en met 6; Bc LbLe 2016/2017, artikel 2 lid 1 sub c; Bc LbDh 2014/2017, artikel 2 lid 1. 
b. Degene die een onderneming uitoefent met een onderdeel: ${ }^{102}$

- waarvan de bedrijfsactiviteiten uitsluitend of in hoofdzaak bestaan uit activiteiten zoals onder $C 1$ tot en met 14 vermeld, en

- waarin het aantal arbeidsuren meer dan $50 \%$ van het totaal aantal arbeidsuren in de onderneming uitmaakt.

Dit geldt niet indien voor die gehele onderneming een andere verplichtstelling inzake een verplichtgesteld bedrijfstakpensioenfonds van kracht is die eerder dan deze verplichtstelling geregistreerd is bij het Ministerie van Sociale Zaken en Werkgelegenheid.

c. Juridisch zelfstandige delen van een groep in de zin van artikel 2:24b BW (Staatsblad 1991, 200) waarvan de bedrijfsactiviteiten uitsluitend of in hoofdzaak bestaan uit activiteiten zoals onder $C 1$ tot en met 14 vermeld.

d. De personeelsvennootschap binnen een groep in de zin van artikel 2:24b BW (Staatsblad 1991, 200) waarvan ten minste $75 \%$ van het totaal aantal arbeidsuren van de werknemers wordt uitgeoefend bij een of meer andere groepsonderdelen waarvan de bedrijfsactiviteiten uitsluitend of in hoofdzaak bestaan uit activiteiten zoals onder $C 1$ tot en met 14 vermeld. 2 Van 'in hoofdzaak' is sprake indien het aantal arbeidsuren van de werknemers in dienst van de werkgever die betrokken zijn bij de activiteiten zoals onder $C 1$ tot en met 14 vermeld meer dan $50 \%$ van het totaal aantal arbeidsuren binnen de onderneming uitmaakt.

3 Deze bepaling geldt met inachtneming van de bepalingen in bijlage II. ${ }^{103}$

De Lb-regelingen ${ }^{104}$ vermelden dat er sprake is van het 'in hoofdzaak' uitoefenen van werkzaamheden binnen de bedrijfstak Lb indien het aantal arbeidsuren van 'de werknemers' in dienst van de werkgever 'die betrokken zijn bij de activiteiten' zoals beschreven in de kwalitatieve werkingssfeerbepalingen van de Lb-regelingen 'meer dan 50\% van het totaal aantal arbeidsuren binnen de onderneming' uit-

102 Voor een onderdeel geldt volgens de letterlijke tekst van de werkingssfeerbepaling in de Lb-regelingen dat dit naar aantal (overeengekomen arbeidsuren van) werknemers een omvangrijk onderdeel kan/moet zijn, nu het aantal arbeidsuren daarvan meer dan $50 \%$ van het totaal aantal arbeidsuren in de onderneming moet uitmaken. Binnen dat onderdeel dienen dan weer de bedrijfsactiviteiten 'uitsluitend of in hoofdzaak' te bestaan uit activiteiten (werkzaamheden) die tot de bedrijfstak Lb behoren (vgl. vb Lb, onder C1 tot en met 14). Indien echter (weliswaar in strijd met de letterlijke tekst van de werkingssfeerbepaling) de term 'onderneming' tevens als 'onderdeel' gelezen mag (moet) worden, kan tevens (bijvoorbeeld) een bij de Kamer van Koophandel ingeschreven vestiging 'met 20 Lb-werknemers' van een besloten vennootschap met (bijvoorbeeld) in totaal 100 werknemers tot de bedrijfstak Lb behoren (zie vb Lb, onder B.1.b). Deze laatste uitleg ligt meer voor de hand. Nu een 'onderdeel' geen zelfstandige drager is van rechten en verplichtingen, is vanzelfsprekend niet die 'onderneming', maar de juridische eenheid als formele werkgever gehouden tot naleving van de Lb-regelingen (vgl. artikel 4 Wet Bpf).

$103 \mathrm{Vb} \mathrm{Lb}$, bijlage III vermeldt een samenloopbepaling ter voorkoming van 'overlappende werkingssferen' tussen enerzijds de takken 'Hoveniers' en 'Bos en Natuur' van de bedrijfstak Lb en anderzijds de bedrijfstak Bouwnijverheid (hierna ook: Bn).

$104 \mathrm{Vb} \mathrm{Lb}$, onder B.2. 
maakt. Dit 'betrokken bij'-criterium ${ }^{105}$ in de Lb-regelingen (voor de Lb-werkgever) staat eveneens in de Me-regelingen ${ }^{106}$ en Mt-regelingen vermeld.

\subsection{Uitsluitend of in hoofdzaak; het 'overeengekomen arbeidsuren'-criterium}

De Me-regelingen vermelden dat een onderneming onder de werkingssfeer valt als daar 'in hoofdzaak' Metalektro-activiteiten ${ }^{107}$ worden verricht. Dan is sprake van een 'werkgever in een onderneming in de Metalektro' (hierna ook: Me-werkgever; artikel 2 lid 1 en $2 \mathrm{vb} \mathrm{Me}):^{108}$

\section{'Artikel 2 Verplichtstelling}

1 Het deelnemen in PME is verplicht gesteld voor werknemers in dienst van een werkgever in een onderneming in de Metalektro.

2 Een onderneming die activiteiten verricht als beschreven in de leden 6 tot en met 7 valt onder de werkingssfeer van deze verplichtstelling als in hoofdzaak Metalektro-activiteiten worden verricht.'

Het 'hoofdzaak'-criterium staat uitgewerkt in het derde lid (artikel 2 lid 3 vb Me):

'3. Of in hoofdzaak activiteiten binnen de Metalektro worden verricht, wordt bepaald aan de hand van het aantal arbeidsuren dat door werknemers van de

105 De betekenis van het woord betrokken is in Van Dale 'in iets gemoeid', terwijl het woord verrichten betekent 'ten uitvoer brengen, syn.: doen, uitvoeren'. Dit 'betrokken bij'-criterium is logischerwijze een 'hoofdverzameling' die de 'deelverzameling' verrichten omvat. Immers, iemand die bepaalde werkzaamheden zelf verricht, is automatisch ook bij die werkzaamheden betrokken. Als iemand bij bepaalde werkzaamheden betrokken is (bijvoorbeeld op een ondersteunende manier), betekent dat natuurlijk niet automatisch dat diegene die werkzaamheden ook zelf verricht. De hoofdverzameling van werkzaamheden die wordt gedekt door het begrip "betrokken (zijn) bij' omvat derhalve naar de aard weliswaar de deelverzameling van werkzaamheden die worden gedekt door het begrip verrichten, maar andersom is dat in zijn algemeenheid niet het geval.

106 De Me-regelingen vermelden dat tevens tot de Me-activiteiten de werkzaamheden behoren van werknemers die in een al dan niet ondersteunende functie ('waartoe mede wordt verstaan werknemers in de overhead') werkzaam zijn ten behoeve van (derhalve betrokken zijn bij) de activiteiten binnen de bedrijfstak Me (vb Me, artikel 2 lid 4). Voor zover werknemers betrokken zijn bij zowel Me-activiteiten als andere ondernemingsactiviteiten, waaronder mede te verstaan activiteiten in enige andere (afzonderlijke) bedrijfstak buiten de Me, wordt het aantal (overeengekomen) arbeidsuren van deze werknemers naar evenredigheid toegerekend aan deze verschillende te onderscheiden activiteiten van de onderneming (vb Me, artikel 2 lid 5). In lijn met onder meer bc Me 2016/2018, artikel 1.2 lid 4 en HR 24 februari 2012, ECLI:NL:HR:2012:BU9889, NJ 2012/142 (Me/Vector). Vgl. Asser/Lutjens 7-XI 2016/309.

$107 \mathrm{Vb} \mathrm{Me}$, artikel 2 lid 6 en 7.

108 Bc Me 2016/2018, artikel 1.2 jo. bijlage A; bc MeAo 2016/2018, artikel 2 jo. bijlage A; en bc MeHp 2016/2018, artikel 1.2 jo. bijlage a. 
onderneming aan die activiteiten wordt besteed. ${ }^{109}$ Van 'in hoofdzaak' is sprake als dat gewoonlijk meer dan $50 \%$ is van de in de onderneming met de werknemers overeengekomen arbeidsuren.'

Voor de kwalificatie als Me-werkgever dient meer dan 50\% van de in de onderneming met de werknemers 'overeengekomen arbeidsuren' aan activiteiten binnen de bedrijfstak Me te worden besteed. Dit 'overeengekomen arbeidsuren'-criterium in de Me-regelingen staat eveneens in de hierna te behandelen Mt-regelingen weergegeven. Het 'aantal arbeidsuren' van 'de werknemers' in dienst van de werkgever 'die betrokken zijn bij de activiteiten' zoals beschreven in de Lb-regelingen, zal logischerwijs (eveneens) het aantal 'overeengekomen arbeidsuren' van deze werknemers betreffen.

De conclusie is dat de bcp-regelingen voor de beoordeling van de toepasselijke werkingssfeer zowel met het 'betrokken bij'-criterium als met het 'overeengekomen arbeidsuren'-criterium werken. Dit ligt ook voor de hand, nu (a) de Me-regelingen en de Mt-regelingen op de in paragraaf 3.4 geschetste onderdelen een materieel-wettelijk systeem vormen, en (b) de hierna te behandelen definitie van het 'uitsluitend of in hoofdzaak'-criterium in de Mt-regelingen een verband legt met andere bedrijfstakken, zoals de Lb en de Me.

\subsection{De relatie tot eerder en later tot stand gekomen bedrijfstakken}

Zoals in paragraaf 2 aangegeven, zijn na de Lb-regelingen, de Me-regelingen en de Mt-regelingen vele andere bcp-regelingen tot stand gekomen. ${ }^{110}$ De vb Mt ver-

109 In de Me-regelingen komt weliswaar (naast het begrip 'overeengekomen arbeidsuren') eveneens het begrip 'bestede arbeidsuren' voor, maar dat doet er niet toe. De grammaticale betekenis in Van Dale is ' 1 (mbt. geestelijke vermogens) in 't werk stellen, syn. aanwenden: kracht, moeite, zorg aan iets besteden 2 (mbt. de tijd) op een bepaalde wijze doorbrengen, gebruiken voor, wijden aan -: zijn tijd, zijn leven nuttig besteden; veel tijd aan iets besteden, geven (...)'. Anders gezegd, het gaat hier dus om het aantal arbeidsuren dat door werknemers van de onderneming aan activiteiten binnen de bedrijfstak Me wordt gewijd of daarvoor wordt gebruikt, hetgeen niets zegt over de doelmatigheid van de activiteiten binnen de bedrijfstak Me; dat is ook niet van belang. Het al dan niet toepasselijk zijn van de werkingssfeer van de Me-relingen (en overigens ook andere bcpregelingen) kan en zal in alle redelijkheid niet afhankelijk (moeten) zijn van de mate van efficiency waarmee of de wijze waarop een onderneming zaken zoals (bijvoorbeeld) vliegtuigen, liften en/of optische apparaten (waaronder camera's) vervaardigt. Dat maakt het al dan niet van toepassing zijn van de werkingssfeer van bcp-regelingen ook niet goed controleerbaar en zal het handhaven van bcp-regelingen bemoeilijken. Een dergelijke (onjuiste en niet, althans moeilijk, te verifiëren) beoordeling van de werkingssfeer impliceert immers dat steeds 'met een stopwatch zal moeten worden gemeten' hoeveel tijd een werknemer exact aan bepaalde bedrijfstakwerkzaamheden besteedt, hetgeen logischerwijs mogelijkheden biedt om bcp-regelingen te ontgaan. Mede hierom, en aangezien het absolute hoofdzaakcriterium in de Me-regelingen is gedefinieerd als 'gewoonlijk meer dan 50\% (...) van de in de onderneming met de werknemers overeengekomen arbeidsuren' en de Me-regelingen in materieel-wettelijk verband staan met de Mt-regelingen, ligt het voor de hand dat deze Me-regelingen net als de Mt-regelingen met het 'overeengekomen arbeidsuren'-criterium als kwantitatief criterium rekenen. Ten slotte vermelden de Me-regelingen (zij het in iets andere bewoordingen) net als de Lb-regelingen en de Mt-regelingen een 'betrokken bij'-criterium dat zich (eveneens) moeilijk laat verenigen met een 'bestede arbeidsuren'-criterium.

110 Er is vooral een grote stijging van het aantal bpf's in de periode tot 1963. 
meldt per 1 januari 1964 het volgende 'hoofdzaak'-criterium, dat een vergelijking maakt met 'werkzaamheden verricht op het gebied van enige andere bedrijfstak' dan de bedrijfstak Mt: ${ }^{111}$

'het deelnemen in het Bedrijfspensioenfonds voor de Metaalnijverheid verplicht te stellen voor alle mannelijke werknemers, die werkzaam zijn in ondernemingen, in welke, ongeacht de economische functie, uitsluitend of in hoofdzaak één of meer van de hierna onder $1 \mathrm{t} / \mathrm{m} 18$ genoemde werkzaamheden worden uitgeoefend.

Een onderneming wordt geacht 'in hoofdzaak' één of meer van de hieronder genoemde werkzaamheden uit te oefenen, wanneer het aantal werknemers, dat bij de bedoelde werkzaamheden is betrokken, groter is dan het aantal werknemers, dat werkzaamheden verricht op het gebied van enige andere bedrijfstak.'

De tekst uit 1964 'werkzaamheden (...) op het gebied van enige andere bedrijfstak' is in 2015 met de tekst 'werkzaamheden zoals uitgeoefend in enige andere afzonderlijke bedrijfstak (buiten de Metaal en Techniek)' verduidelijkt. De strekking van de werkingssfeerbepaling is hetzelfde gebleven. ${ }^{112}$ Het begrip 'uitsluitend of in hoofdzaak' is in de Mt-regelingen uitgewerkt ${ }^{113}$ in de definitie van het begrip 'werkgever in de Metaal Techniek' (vb Mt): ${ }^{114}$

'22. Onder 'werkgever in de Metaal en Techniek' wordt in deze Verplichtstellingsbeschikking verstaan de werkgever bij wie uitsluitend of in hoofdzaak een of meer van de hiervoor in de artikelen $1 \mathrm{t} / \mathrm{m} 17$ genoemde werkzaamheden worden uitgeoefend, dat wil zeggen de werkgever bij wie het aantal overeengekomen arbeidsuren van de in dienst zijnde werknemers die betrokken zijn $^{115}$ bij de werkzaamheden zoals uitgeoefend in de in artikelen $1 \mathrm{t} / \mathrm{m} 17$ genoemde bedrijfstakken (binnen de Metaal en Techniek), groter is dan het aantal overeengekomen arbeidsuren van de in dienst zijnde werknemers die betrokken zijn bij werkzaamheden zoals uitgeoefend in enige andere afzonderlijke bedrijfstak (buiten de Metaal en Techniek), blijvende bij de hier voren

111 Stcrt. 31 december 1963, 252, onder III. De (avv-bepalingen van de) cao Loodgieters- en fittersbedrijf van 1962 (behorende tot de bedrijfstak Mt) vermeldt in artikel 1 lid 3 dezelfde tekst.

112 Uit de bekendmaking van het verzoek tot wijziging van vb Mt (Stcrt. 2015, 7042) blijkt dat deze wijziging ter verduidelijking en actualisering dient. Daarmee wordt dus geen materiële wijziging beoogd.

113 Gezien de tekst na de woorden 'dat wil zeggen' in de definitie.

114 Vb Mt, artikel 22. Vgl. bc MtMb 2017/2019, artikel 4a. Vgl. bc MtTi 2017/2019, artikel 4a; bc Avim 2014/2018, artikel 1 sub E; en bc Sfm 2014/2018, artikel 1 sub E.

115 Het woord 'zijn' slaat op het woord 'werknemers' in diezelfde regel. Indien beoogd wordt te verwijzen naar het (enkelvoudige) woord 'aantal', dan zou er staan: 'dat betrokken is bij' in plaats van 'die betrokken zijn bij'. Dit betekent dat voor een (kwalitatieve en kwantitatieve) beoordeling van de werkingssfeer allereerst 'de werknemers die betrokken zijn bij de werkzaamheden' in de bedrijfstak Mt dienen te worden (op)geteld (de 'eerste telling') en vervolgens 'het aantal met hen overeengekomen arbeidsuren' (voltijds dan wel deeltijds) dient te worden (op)geteld (de 'tweede telling'). 
omschreven vergelijking de economische functie van elk der werkzaamheden buiten beschouwing.'

De vorenstaande definitie vermeldt, net als de Me-regelingen en de Lb-regelingen, naast het 'betrokken bij'-criterium tevens het 'overeengekomen arbeidsuren'criterium. Bij een 'werkgever in de Metaal en Techniek' (hierna: Mt-werkgever) zijn de (overeengekomen arbeidsuren van de) werknemers in hoofdzaak betrokken bij werkzaamheden zoals uitgeoefend in de bedrijfstakken binnen de Mt. De (overeengekomen arbeidsuren van de) werknemers in enige andere afzonderlijke bedrijfstak buiten de Mt vormen de bijzaak. De uitwerking van het 'uitsluitend of in hoofdzaak'-criterium in de hiervoor weergegeven definitie vermeldt de zinsnede 'groter is dan' (en derhalve geen begrippen zoals het merendeel of meer dan $50 \%) .{ }^{116}$ De zinsnede 'groter is dan' betreft de vergrotende comparatieve trap van het bijvoeglijke naamwoord 'groot' en geeft aan dat de werknemers 'in hogere mate' (en dus niet in welke mate) betrokken zijn bij werkzaamheden binnen de Mt dan bij werkzaamheden zoals uitgeoefend in enige andere afzonderlijke bedrijfstak buiten de Mt. ${ }^{117}$ Gesteld kan worden dat de Mt-regelingen aldus een 'relatieve hoofdzaak'-criterium vermelden (feitelijk een $\leq 50 \%$ of $\geq 50 \%$-criterium in relatie tot enige andere afzonderlijke bedrijfstak buiten de $\mathrm{Mt}$ ). ${ }^{118}$ De Lb-regelingen en de Me-regelingen vermelden blijkens hun tekst een 'absolute hoofdzaak'-criterium (feitelijk een > 50\%-criterium). ${ }^{119}$ Ten slotte vermelden al deze bcp-regelingen daarbij het 'uitsluitend'-criterium (feitelijk een 100\%-criterium).

\subsection{De absolute dan wel relatieve hoofdzaak in de bedrijfstak}

De bcp-regelingen vermelden een 'absolute hoofdzaak'-criterium. Daarnaast vermelden de Mt-regelingen een 'relatieve hoofdzaak'-criterium. Stel dat de (overeengekomen arbeidsuren van de) werknemers van een werkgever in de verhouding 40\% Mt: 30\% $\mathrm{Me}^{120}: 30 \% \mathrm{Lb}$ over de bedrijfstakken vallen te verdelen. In dit

116 Anders dan het Gerechtshof Den Bosch bij arrest van 12 augustus 2014, ECLI:NL:GHSHE: 2014:2769, JAR 2014/228 (Mt/Projectsourcing) oordeelt, betekent de term hoofdzaak geenszins 'het merendeel' en al helemaal niet 'in het normale spraakgebruik (...) meer dan $50 \%$ van de activiteiten', maar '(de) belangrijkste (...) zaak' en het tegenovergestelde van 'bijzaak', oftewel dient de hoofdzaak te worden onderscheiden van de bijzaak (Van Dale).

117 Zie www.taalunie.org.

118 Van Dale: relatief: 'ten opzichte van iets anders, afhangende van iets anders, syn. betrekkelijk, tgov. absoluut'.

119 Van Dale: absoluut: 'niet beschouwd in betrekking met iets soortgelijks, syn. volstrekt, tgov. relatief'.

120 Het betreft noch Mb-werkzaamheden, noch Ti-werkzaamheden. 
voorbeeld betreft de bedrijfstak Mt de relatieve hoofdzaak. ${ }^{121}$ Op welke wijzen kan deze situatie worden bezien? Indien het voorbeeld drie afzonderlijke onderdelen (bijvoorbeeld vestigingen) van de totale onderneming (de juridische eenheid) betreft, kan worden gesproken van een Mt-vestiging, een Me-vestiging en een Lb-vestiging, waarop de respectieve bcp-regelingen van toepassing zijn. Wat nu indien er geen onderdelen van de onderneming vallen aan te wijzen en toch sprake is van een in meerdere bedrijfstakken gespecialiseerde werkgever, zoals in het voorbeeld? In dit laatste geval lijkt toepassing van het 'relatieve hoofdzaak'criterium juist. Vooral bij een werkgever die (zoals in het voorbeeld) dicht tegen de 50\% Mt aan zit, lijkt dit terecht. In dat geval kan ook worden gezegd dat de Mt-werkzaamheden 'de kern en het zwaartepunt' van (en dus) de (eigenlijke) bedrijfstakactiviteiten betreffen. ${ }^{122}$ Het als kwantitatieve maatstaf voor de beoordeling van de werkingssfeer slechts toepassen van het 'uitsluitend'-criterium dan wel het 'absolute hoofdzaak'-criterium biedt de werkgever in het voorbeeld mogelijkheden de werkingssfeer van bcp-regelingen te ontgaan. Zo kan deze werkgever bijvoorbeeld door slechts een paar werknemers meer of minder in dienst te nemen of een andere functie te geven eenvoudig sturen op het omslagpunt van $50 \%$ om zo buiten de reikwijdte van alle genoemde bcp-regelingen te blijven. ${ }^{123}$ Het 'relatieve hoofdzaak'-criterium van de Mt-regelingen voorkomt dit en vervult als het ware een 'vangnetfunctie' c.q. 'schakelfunctie'. De betreffende werkgever heeft de keuze ofwel de Mt-regelingen op de juridische eenheid toe te passen (de 'vangnetfunctie'), ofwel de arbeid alsnog in drie afzonderlijke (bedrijfstak)onderdelen onder te brengen (de 'schakelfunctie'). Wellicht betreft het voorbeeld een uitzonderingssituatie. Er dient blijkens de tekst van de Mt-regelingen hoe dan ook een kwantitatieve afweging te worden gemaakt tussen enerzijds de bedrijfstak Mt en anderzijds de afzonderlijke bedrijfstakken buiten de Mt. Het gerechtshof te Den Bosch overweegt op 12 april 2011 terecht het volgende: ${ }^{124}$ 'De Fondsen leggen de (...) definitie van het begrip werkgever aldus uit dat het aantal overeengekomen arbeidsuren van de werknemers die betrokken zijn bij 'werkzaamheden uitgeoefend in enige ${ }^{125}$ andere tak van bedrijf per afzonderlijke andere tak van

121 Weliswaar beoogt het Gerechtshof Den Bosch bij JAR 2014/228 (Mt/Projectsourcing) terug te komen op zijn (juiste) uitleg van het hoofdzaakcriterium in het door hem op 12 april 2011 gewezen arrest in de zaak Mt/Laudam (ECLI:NL:GHSHE:2011:BQ1268), maar die zaak (Mt/Projectsourcing) is door de Hoge Raad op 10 juni 2016 met hantering van artikel 81 Wet RO afgedaan (ECLI:NL:HR:2016:1172, JAR 2016/167). Het is de vraag welke waarde aan dit laatste oordeel moet worden gehecht (immers bekrachtigt de Hoge Raad een arrest niet), temeer nu het gerechtshof tevens oordeelt dat er slechts werkingssfeerinformatie met betrekking tot een betrekkelijk korte periode voorhanden was ('een momentopname', r.o. 7.5.7, 7.6.1 en 7.6.2). Daarbij is het arrest van het gerechtshof op het onderdeel van de uitleg van het hoofdzaakcriterium onbegrijpelijk. Dit met name blijkens r.o. 7.5.5 van het arrest: 'Dat leidt er toe dat dan ook redelijkerwijs de hier gebezigde bewoordingen "dan in enige andere tak van bedrijf" moeten worden uitgelegd als "dan in alle andere takken van het bedrijf tezamen".'

122 HR 31 januari 2014, ECLI:NL:HR:2014:215, r.o. 3.4, NJ 2014/102 (Me/Adimec).

123 Ook de A-G ziet dat het begrip 'hoofdzaak' taalkundig bezien niet noodzakelijk op een getalsmatige meerderheid in de zin van meer dan de helft ziet (conclusie nr. 3.30.2, 18 maart 2016, ECLI:NL:PHR:2016:166 en JAR 2016/167 (Mt/Projectsourcing).

124 ECLI:NL:GHSHE:2011:BQ1268 (Mt/Laudam), r.o. 4.6, 4.6.3, 4.7, 4.15.1, 4.15.5 en 4.16.

125 Van Dale: 'één of andere', 'waarvan er geen tweede is' en 'tautologie is enig en alleen'. 
bedrijf moet worden vergeleken met het aantal overeengekomen arbeidsuren van de werknemers die betrokken zijn bij M\&T werkzaamheden.' Deze beoordeling van de toepasselijke werkingssfeer erkent zowel het belang van concurrentiebeperking op arbeidsvoorwaarden binnen een bedrijfstak als het belang van de vb van een bpf. Dit laatste betreft zowel het verkleinen van de 'witte vlek' (het gebied waar werkgevers geen pensioenregeling voor hun werknemers hebben getroffen) als het verkleinen van de 'grijze vlek' (het gebied waar werkgevers een pensioenregeling van inferieure kwaliteit hebben getroffen). ${ }^{126}$ Voor het geval de toepassing van deze regel op problemen stuit, bestaat voor een werkgever de mogelijkheid vrijstelling van deelneming in het bpf $^{127}$ aan te vragen en dispensatie van toepassing van de $b c^{128}$ te verzoeken. Ten slotte kan de werkgever ook een beroep op de beperkende werking van de redelijkheid en billijkheid doen. ${ }^{129}$

\subsection{De tien uitgangspunten voor de berekening van de werkingssfeer}

Zoals gezegd, kan er tot een model voor de berekening van de werkingssfeer worden gekomen indien er patronen en relaties binnen en tussen de drie bedrijfstakken worden gevonden en daaraan variabelen (en dus getallen) kunnen worden gekoppeld. Op basis van de gevonden patronen en relaties kunnen allereerst de volgende tien uitgangspunten voor de beoordeling van de werkingssfeer van de bcp-regelingen worden geformuleerd:

1 Er zijn bcp-regelingen in de te onderscheiden drie bedrijfstakken.

2 Zij betreffen een $b p f$, meerdere $b c$ 's en één of meerdere $b c f s$.

3 De regelingen vermelden begrippen zoals 'werknemer', 'werkgever' en '(onderdeel van een) onderneming'.

4 Als kwantitatief werkingssfeercriterium geldt dat de bedrijfsactiviteiten van een werkgever 'uitsluitend of in hoofdzaak' bestaan uit bedrijfstakwerkzaamheden.

5 Voor het kwalitatief werkingssfeercriterium zijn de in de regelingen vermelde bedrijfstakwerkzaamheden relevant.

6 Het aantal werknemers dat 'betrokken is bij' de bedrijfstakwerkzaamheden is van belang voor het 'uitsluitend of in hoofdzaak'-criterium.

7 Ook de met de sub 6 bedoelde werknemers 'overeengekomen arbeidsuren' zijn van belang voor het 'uitsluitend of in hoofdzaak'-criterium.

126 Bakels e.a. 2017, par. 5.3.1; Lutjens 1999, p. 14 e.v.; Asser/Lutjens 7-XI 2016/264 en 265. Toetsingskader-avv, onder 1 en Toetsingskader-bpf (ook Stcrt. 15 december 2011, 22535, p. 1 en 2, onder 1$)$.

127 Artikel 13 Wet Bpf.

128 Toetsingskader-avv, par. 7 en zie ook par. 2: 'Indien cao-partijen in hun cao een dispensatiebepaling hebben opgenomen en daarvoor avv hebben aangevraagd en verkregen kan door ondernemingen die via avv aan de cao zijn gebonden een beroep op deze dispensatiebepaling worden gedaan.'

129 Artikel 6:248 BW. Iedere rekenregel kan onredelijke (rechts)gevolgen met zich meebrengen. Van geval tot geval moet dit worden bezien. NJ 2005/493 (Pensioenfonds DSM Chemie/Fox), r.o. 4.5: '(...) rechtspraak heeft als gemeenschappelijke grondslag dat bij de uitleg van een schriftelijk contract telkens van beslissende betekenis zijn alle omstandigheden van het concrete geval, gewaardeerd naar hetgeen de maatstaven van redelijkheid en billijkheid meebrengen'. 
8 De hiërarchie tussen de bcp-regelingen maakt eveneens dat werkzaamheden aan bcp-regelingen kunnen worden toegerekend.

9 De 'economische functie van de werkzaamheden' van de werknemers en de 'economische functie van de onderneming' van de werkgever zijn niet relevant.

$10 \mathrm{Bij}$ de beoordeling van de werkingssfeer gaat het om een kwalitatieve en kwantitatieve afweging tussen de te onderscheiden bedrijfstakken.

Uit deze tien uitgangspunten kunnen de variabelen die voor de berekening van de toepasselijke werkingssfeer van bcp-regelingen van belang zijn, worden gedestilleerd.

\subsection{De variabelen en de wijze van berekening van de werkingsfeer}

Het (1) aantal overeengekomen arbeidsuren ('uren', hierna: 'u') van (2) het aantal werknemers dat betrokken is bij bedrijfstakwerkzaamheden ('arbeid', hierna: 'a') is (zijn) relevant als variabele(n) voor de berekening van de werkingssfeer. Het is voor de beoordeling of een werkgever kwalificeert als een Mt-werkgever, een Mewerkgever of een Lb-werkgever de aangewezen weg om de beschikking te hebben over de volgende informatie en de volgende berekeningswijze toe te passen:

a Het betreft ten eerste (kwalitatieve) informatie, zoals de functies van de werknemers en de werkzaamheden gemoeid met de te onderscheiden functies, en (kwantitatieve) informatie, zoals het aantal werknemers per functie en per werknemer de met de betreffende werknemer overeengekomen arbeidsuren (voltijds dan wel deeltijds). ${ }^{130}$

b Vervolgens, ten tweede, dient het aantal (overeengekomen arbeidsuren van) werknemers betrokken bij werkzaamheden in (bijvoorbeeld) de bedrijfstakken binnen de $\mathrm{Mt}$ te worden afgezet tegen het aantal (overeengekomen arbeidsuren van) werknemers betrokken bij werkzaamheden in enige andere afzonderlijke bedrijfstak buiten de Mt, zoals de bedrijfstak Lb of de bedrijfstak Me.

Voor een (kwalitatieve en kwantitatieve) beoordeling van de werkingssfeer dienen derhalve allereerst 'de werknemers die betrokken zijn bij de werkzaamheden' in de te onderscheiden afzonderlijke bedrijfstakken te worden (op)geteld (de eerste telling) en vervolgens 'het aantal met hen overeengekomen arbeidsuren' (voltijds dan wel deeltijds) te worden (op)geteld (de tweede telling). ${ }^{131}$ Op basis van de variabelen (1) het 'aantal werknemers betrokken bij bedrijfstakwerkzaamheden' en (2) het 'aantal met hen overeengekomen arbeidsuren' kan dus tot een rekenmodel

130 Vgl. artikel 7:655 BW.

131 Het Gerechtshof Den Bosch oordeelt op 12 mei 2009 dat vier van de vijf werknemers 'betrokken zijn bij' de productie van metalen voorwerpen en daarom de werkingssfeer van de Mt-regelingen van toepassing is (ECLI:NL:GHSHE:2009:BJ0902, r.o. 4.11.1 e.v., PJ 2011/50 (Mt/Mimeos)). Het Gerechtshof Den Bosch oordeelt op 26 september 2017: 'Het criterium verwijst niet naar het aantal overeengekomen arbeidsuren "dat wordt besteed aan" bedrijfstakactiviteiten. Het gaat daarom om het aantal met de werknemers overeengekomen arbeidsuren van die werknemers die betrokken zijn bij werkzaamheden die onder de bedrijfstakomschrijving vallen' (ECLI:NL:GHSHE:2017:4175, r.o. 10.32.3, PJ 2017/163 (Mt/Stinissen)). 
worden gekomen. De functie van de werknemer en de daarmee gemoeide werkzaamheden ('a') en de met deze werknemer voltijds dan wel deeltijds overeengekomen arbeidsuren (' $u$ ') zullen steeds (als variabelen) aan een afzonderlijke bedrijfstak kunnen worden toegerekend ter vaststelling van de op de werkgever toepasselijke werkingssfeer van bcp-regelingen.

\section{$4 \quad$ Een rekenmodel voor de vaststelling van de werkingssfeer}

\subsection{De met het oog op de toerekening relevante verzamelingen}

Bij de beoordeling van de toepasselijke werkingssfeer kan het toerekenen van (werkzaamheden van) werknemers aan te onderscheiden bedrijfstakken een moeilijke puzzel opleveren. Figuur 3 kan bij die toerekening behulpzaam zijn. Ten eerste sluit het in deze figuur vermelde (a) 'uitsluitend'-criterium het (b) 'absolute hoofdzaak'-criterium uit, terwijl dit laatste criterium (c) het 'relatieve hoofdzaak'criterium uitsluit. Dit sluit natuurlijk niet uit dat een (onderneming van een) werkgever 'zowel uitsluitend als in hoofdzaak' kwalificeert als een bedrijfstakwerkgever.

\section{Figuur 3 Werknemers, werkzaamheden, overeengekomen arbeidsuren en onderneming}

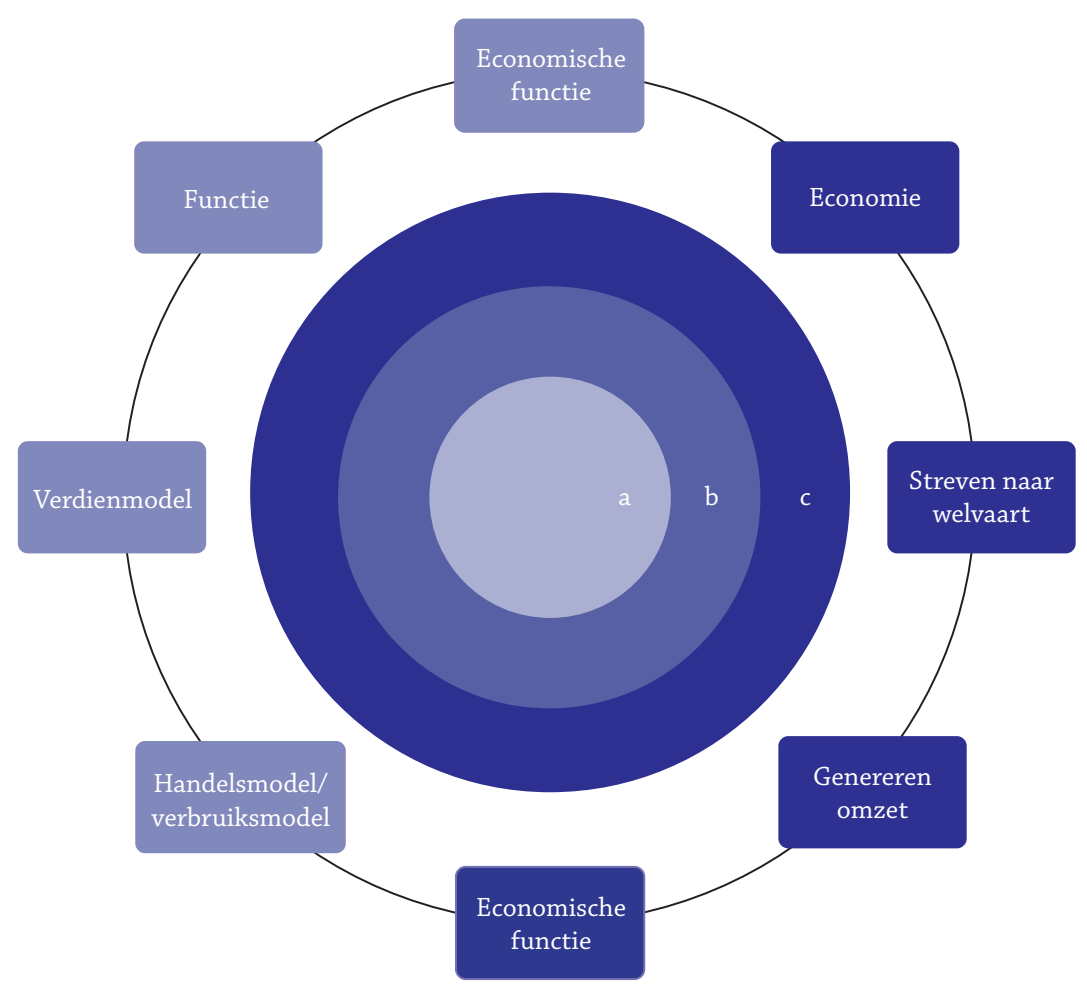


Ten tweede kan figuur 3 als de onderneming van de werkgever worden gezien. De onderneming heeft (blijkens de buitenste schil) een economische functie, te weten een verdienmodel waarmee de onderneming omzet genereert. Deze economische functie van de onderneming van de werkgever is niet relevant voor de beoordeling of een werkgever kwalificeert als een Mt-werkgever, een Me-werkgever of een Lb-werkgever. Ten derde kan figuur 3 op de volgende onderwerpen worden gezien als een hoofdverzameling met zich daarbinnen bevindende deelverzamelingen:

1 Het totale aantal werknemers van de onderneming. Er vallen dan werknemers aan te wijzen die bedrijfstakwerkzaamheden (a) verrichten, (b) daarbij betrokken zijn ${ }^{132}$ en (c) daarbij indirect betrokken zijn. ${ }^{133}$

2 De totale werkzaamheden binnen de onderneming. Er vallen dan werkzaamheden aan te wijzen als (a) het verrichten van bedrijfstakwerkzaamheden, (b) betrokken bij bedrijfstakwerkzaamheden en (c) indirect betrokken bij bedrijfstakwerkzaamheden.

3 Het totale aantal overeengekomen arbeidsuren van een werknemer binnen de onderneming. Er vallen dan arbeidsuren aan te wijzen die (a) met het verrichten van bedrijfstakwerkzaamheden gemoeid zijn, (b) betrokken zijn bij bedrijfstakwerkzaamheden en (c) indirect betrokken zijn bij bedrijfstakwerkzaamheden.

4 De berekening van de werkingssfeer. Ten eerste dienen (a) de werknemers die (b) betrokken zijn bij bedrijfstakwerkzaamheden te worden (op)geteld. Ten tweede (c) dienen de met deze werknemers overeengekomen arbeidsuren te worden opgeteld.

Aldus is figuur 3 een zogenoemd 'ui-model' (met relevante verzamelingen), dat met het oog op de toerekening van (werkzaamheden van) werknemers aan bcpregelingen in acht kan worden genomen. Bij de toerekening van bedrijfstakwerkzaamheden aan een (of meer) werknemer(s) geldt steeds voor de 'variabele a' dat zowel het verrichten van bedrijfstakwerkzaamheden als het betrokken zijn bij bedrijfstakwerkzaamheden van belang is. Ten slotte dienen de met deze werknemer(s) voltijds dan wel deeltijds overeengekomen arbeidsuren ('variabele u') te worden (op)geteld. Figuur 3 komt in paragraaf 4.4 en 4.5 nader aan de orde. Het is weliswaar mooi op basis van gevonden variabelen tot een rekenmodel te komen, maar is dit ook toepasbaar in de praktijk? Op deze vraag wordt hierna met enkele rekenvoorbeelden ingegaan.

\subsection{Enkele rekenvoorbeelden met de variabelen van de drie bedrijfstakken}

Hoe kan de werkingssfeer (hierna: 'W') worden berekend indien een werknemer 'structureel en stelselmatig' voor een deel (van de met hem overeengekomen arbeidsuren) betrokken is bij werkzaamheden in de bedrijfstak Mt en voor het

132 Bijvoorbeeld werknemers in een 'ondersteunende functie', zoals vermeld in de Me-regelingen. Hierbij kan worden gedacht aan een werknemer die vliegtuigonderdelen aan- en afvoert ten behoeve van de vliegtuigmonteurs.

133 Vgl. de werknemers in de 'overhead' zoals (bijvoorbeeld) vermeld in vb Me, artikel 2 lid 4. Hierbij kan worden gedacht aan een werknemer die de salarisadministratie van de vliegtuigmonteurs verzorgt. Vgl. NJ 2012/142 (Me/Vector) r.o. 3.5.5. 


\section{Figuur 4 De volledige overeengekomen arbeidsuren}

\begin{tabular}{|llll|}
\hline \multicolumn{1}{|c|}{} & Werknemer & Lb & Mt \\
\cline { 2 - 4 } & Nummer 1 & 40 uur & 40 uur \\
& Nummer 2 & & 40 uur \\
& Nummer 3 & & 40 uur \\
& Nummer 4 & & 40 uur \\
\hline \multirow{2}{*}{ Totaal } & 4 werknemers & 40 uur & 160 uur \\
& & & \\
\hline
\end{tabular}

andere deel (van de met hem overeengekomen arbeidsuren) betrokken is bij werkzaamheden in enige andere afzonderlijke bedrijfstak, zoals de bedrijfstak Lb? In figuur 4 volgt een voorbeeld.

In figuur 4 zijn 4 werknemers betrokken bij werkzaamheden in de bedrijfstak Mt. Een van deze 4 werknemers is gedeeltelijk betrokken bij werkzaamheden in de bedrijfstak Mt (als metaalbewerker in de fabriek) en gedeeltelijk betrokken bij werkzaamheden in de bedrijfstak Lb (als hovenier buiten de fabriek). ${ }^{134}$ Overeenkomstig de tekst van de behandelde werkingssfeerbepalingen vallen de volledige 'overeengekomen arbeidsuren' $(u)$ van deze werknemer aan zowel de bedrijfstak Lb als de bedrijfstak Mt toe te rekenen. De met deze werknemer overeengekomen arbeidsuren bedragen (voor het maken van een kwantitatieve afweging tussen de te onderscheiden bedrijfstakken) derhalve steeds 40 uur per week. Allereerst dienen de (werkzaamheden van de) werknemers aan de te onderscheiden bedrijfstakken te worden toegerekend $(a)$.

$a_{M t}=4$ en $a_{L b}=1$

Hieruit blijkt dat 4 werknemers betrokken zijn bij Mt-werkzaamheden en 1 (van diezelfde 4) werknemer(s) tevens betrokken is bij Lb-werkzaamheden. Vervolgens dient per werknemer het aantal overeengekomen arbeidsuren te worden vastgesteld (u).

$u_{M t}=40$ en $u_{L b}=40$

Hieruit blijkt dat iedere werknemer steeds 40 uur per week werkzaam is. Door per te onderscheiden bedrijfstak het aantal werknemers $(a)$ te vermenigvuldigen met het aantal overeengekomen arbeidsuren $(u)$ kan de werkingssfeer $(W)$ worden uitgerekend.

$134 \mathrm{Vb}$ Lb, bijlage II vermeldt overigens onder d. (Hoveniersbedrijf) sub i: 'Als op een onderneming meerdere verplichtstellingen van toepassing kunnen zijn, hoeft deze verplichtstelling niet te worden toegepast indien de onder $C 5$ genoemde bedrijfsactiviteiten [behorende tot het Hoveniersbedrijf; $\mathrm{MH}$ ] ondergeschikte betekenis hebben in de bedrijfsvoering.' 
Figuur 5 Slechts 1 deeltijdwerknemer

\begin{tabular}{|lllll|}
\hline \multicolumn{1}{|c}{} & Werknemer & Lb & Me & Mt \\
\cline { 2 - 4 } & Nummer 1 & 20 uur & 20 uur & 20 uur \\
& Nummer 2 & & & 40 uur \\
& Nummer 3 & & 40 uur \\
& Nummer 4 & & & 40 uur \\
Totaal & 4 werknemers & 20 uur & 20 uur & 140 uur \\
& & & & \\
\hline
\end{tabular}

$$
\begin{aligned}
& W_{M t}=a_{M t} \times u_{M t} \Leftrightarrow 4 \times 40=160 \\
& W_{L b}=a_{L b} \times u_{L b} \Leftrightarrow 1 \times 40=40 \\
& W_{M t}>W_{L b} \Rightarrow W_{M t}
\end{aligned}
$$

Hieruit blijkt dat het aantal overeengekomen arbeidsuren (160) van werknemers betrokken bij de bedrijfstak Mt (4) groter is dan het aantal overeengekomen arbeidsuren (40) van werknemers betrokken bij de bedrijfstak Lb (1). Bijgevolg kwalificeert de betreffende werkgever dan als een Mt-werkgever.

a De overeengekomen arbeidsuren worden in figuur 4 per werknemer per bedrijfstak gemaximeerd.

b De toepasselijkheid van bcp-regelingen is aldus onafhankelijk van de exact door een werknemer bestede tijd aan werkzaamheden in de betreffende bedrijfstak.

c In figuur 4 is niet meer dan $25 \%$ van het totale aantal arbeidsuren van de werknemers toe te rekenen aan de bedrijfstak Lb. ${ }^{135}$

d Bij een 50:50 verdeling van de arbeidsuren van de werknemer tussen de bedrijfstak $\mathrm{Lb}$ en de bedrijfstak $\mathrm{Mt}$ is maximaal $12,5 \%$ van het totale aantal arbeidsuren toe te rekenen aan de bedrijfstak Lb. ${ }^{136}$

e De benadering sub d pakt logischerwijs ook nadeliger uit voor de bedrijfstak $\mathrm{Me}$ indien in het voorbeeld de bedrijfstak Lb wordt vervangen door de bedrijfstak Me.

Het kan zo zijn dat een werkgever met één of meerdere van zijn werknemers schriftelijk is overeengekomen dat hij (of zij) gedurende de arbeidsovereenkomst 'structureel en stelselmatig' betrokken is (of zijn) bij werkzaamheden in meerdere te onderscheiden bedrijfstakken en dat de bijbehorende overeengekomen arbeidsuren afwijken van de in figuur 4 weergegeven situatie. In figuur 5 zijn bij een werkgever 4 werknemers in dienst: 3 zijn voltijds (voor 40 uur per week) in de bedrijfstak Mt werkzaam, en 1 is in deeltijd werkzaam (voor 20 uur per week) in drie te onderscheiden bedrijfstakken, te weten $\mathrm{Lb}, \mathrm{Me}$ en $\mathrm{Mt}$. 


\section{Figuur 6 Meerdere deeltijdwerknemers}

\begin{tabular}{|c|c|c|c|c|}
\hline & Werknemer & $\mathrm{Lb}$ & $\mathrm{Me}$ & Mt \\
\hline & Nummer 1 & 20 uur & 20 uur & 20 uur \\
\hline & Nummer 2 & 20 uur & 20 uur & 20 uur \\
\hline & Nummer 3 & 20 uur & 20 uur & 20 uur \\
\hline & Nummer 4 & & & 40 uur \\
\hline Totaal & 4 werknemers & 60 uur & 60 uur & 100 uur \\
\hline
\end{tabular}

Allereerst dienen de (werkzaamheden van de) werknemers aan de te onderscheiden bedrijfstakken te worden toegerekend $(a)$.

$a_{M t}=4$ en $a_{L b}=1$ en $a_{M e}=1$

Hieruit blijkt dat 4 werknemers betrokken zijn bij Mt-werkzaamheden en 1 (van diezelfde 4) werknemer(s) tevens betrokken is bij zowel Lb-werkzaamheden als Me-werkzaamheden. Vervolgens dient per werknemer het aantal overeengekomen arbeidsuren te worden vastgesteld $(u)$ en per te onderscheiden bedrijfstak het aantal werknemers $(a)$ te worden vermenigvuldigd met het aantal overeengekomen arbeidsuren $(u)$. Aldus kan de werkingssfeer $(W)$ worden uitgerekend.

$$
\begin{aligned}
& W_{M t}=a_{M t} \times u_{M t} \Leftrightarrow(3 \times 40)+(1 \times 20)=140 \\
& W_{L b}=a_{L b} \times u_{L b} \Leftrightarrow 1 \times 20=20 \\
& W_{M e}=a_{M e} \times u_{M e} \Leftrightarrow 1 \times 20=20 \\
& W_{M t}>W_{L b} \vee W_{M t}>W_{M e} \Rightarrow W_{M t}
\end{aligned}
$$

Hieruit blijkt dat het aantal overeengekomen arbeidsuren (140) van werknemers betrokken bij de bedrijfstak Mt (4) groter is dan het aantal overeengekomen arbeidsuren (20) van werknemers betrokken bij de bedrijfstak Lb (1) en groter is dan het aantal overeengekomen arbeidsuren (20) van werknemers betrokken bij de bedrijfstak $\mathrm{Me}$ (1). Bijgevolg kwalificeert de betreffende werkgever dan, na een kwantitatieve afweging tussen te onderscheiden bedrijfstakken, als een Mt-werkgever.

In figuur 6 zijn bij een werkgever wederom 4 werknemers in dienst: 3 zijn in deeltijd werkzaam (voor 20 uur per week) in drie te onderscheiden bedrijfstakken, te weten wederom Lb, Me en Mt, en slechts 1 van de 4 werknemers is voltijds werkzaam in de bedrijfstak Mt (voor 40 uur per week).

Allereerst dienen de (werkzaamheden van de) werknemers aan de te onderscheiden bedrijfstakken te worden toegerekend (a).

$a_{M t}=4$ en $a_{L b}=3$ en $a_{M e}=3$ 
4 werknemers zijn betrokken bij Mt-werkzaamheden en 3 (van diezelfde 4) werknemers zijn tevens betrokken bij zowel Lb-werkzaamheden als Me-werkzaamheden. Vervolgens dient per werknemer het aantal overeengekomen arbeidsuren te worden vastgesteld $(u)$ en per te onderscheiden bedrijfstak het aantal werknemers (a) te worden vermenigvuldigd met het aantal overeengekomen arbeidsuren $(u)$. Aldus kan de werkingssfeer $(W)$ worden uitgerekend.

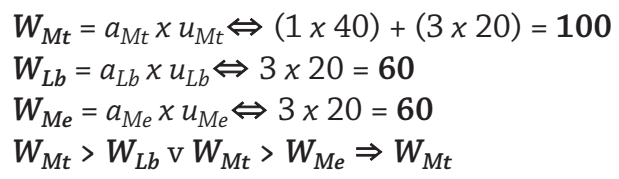

Het aantal overeengekomen arbeidsuren (100) van werknemers betrokken bij de bedrijfstak Mt (4) is groter dan het aantal overeengekomen arbeidsuren (60) van werknemers betrokken bij de bedrijfstak $\mathrm{Lb}$ (3) en is groter dan het aantal overeengekomen arbeidsuren (60) van werknemers betrokken bij de bedrijfstak Me (3). Bijgevolg kwalificeert de betreffende werkgever dan, na een kwantitatieve afweging tussen te onderscheiden bedrijfstakken, als een Mt-werkgever. ${ }^{137}$

\subsection{Het patroon van gelaagde werkingssferen van de te onderscheiden bcp- regelingen}

Indien een werkgever als een Mt-werkgever kwalificeert, dient vervolgens te worden beoordeeld welke Mt-regelingen deze moet toepassen. Een vergelijkbare vervolgvraag doet zich voor indien de werkgever een Me-werkgever of een Lbwerkgever is. Voor het antwoord op deze vraag is van belang te weten dat de werkingssferen binnen de te onderscheiden drie bcp-regelingen met elkaar verband houden en op logische wijze in elkaars verlengde liggen. De te onderscheiden drie bcp-regelingen hebben een patroon van gelaagde werkingssferen. Dit blijkt uit het volgende:

a De in paragraaf 3.7 vermelde definitie van het kernbegrip 'werkgever in de Metaal en Techniek' vormt de denkbeeldige toegangspoort tot het bedrijfstaklandschap van de Metaal en Techniek. Indien uit een kwantitatieve vergelijking met te onderscheiden bedrijfstakken buiten de bedrijfstak Mt volgt dat er sprake is van een 'werkgever in de Metaal en Techniek', dan valt een dergelijke Mt-werkgever wettelijk verplicht onder de werkingssfeer van vb Mt (voor het bpf). Ook valt deze Mt-werkgever dan onder de werkingssfeer van de algemeen verbindend verklaarde bepalingen van de bc Avim (voor het

137 In lijn hiermee oordeelde (bijvoorbeeld) het Gerechtshof Den Bosch dat 4 van de 5 werknemers van een werkgever betrokken zijn bij het vervaardigen van metalen matrijzen en telt het de met hen overeengekomen arbeidsuren op (4 maal 40 uur, derhalve 160 uur). Het gerechtshof acht niet van belang dat de (noodzakelijke) voorbereidende werkzaamheden (om de metalen matrijzen te vervaardigen) van de werknemers meer arbeidstijd in beslag nemen dan de tijd die gemoeid is met de daadwerkelijke vervaardiging van de matrijzen, waarbij het gerechtshof tevens in aanmerking neemt dat de werkgever uitsluitend het vervaardigen van de metalen matrijzen tot doel heeft (PJ 2011/50, (Mt/Mimeos), r.o. 4.11.1. e.v.). Vgl. tevens PJ 2017/163 (Mt/Stinissen). 
schadeverzekeringsfonds) en (bijvoorbeeld) de bc Sfm (voor een sociaal fonds).

b De werkingssfeerbepalingen binnen de bedrijfstak Mt van zowel de bc's met horizontale bepalingen (met normatieve arbeidsvoorwaarden) als van de bc's met diagonale bepalingen (voor bijvoorbeeld de opleidingsfondsen) vermelden weliswaar hetzelfde begrip 'werkgever in de Metaal en Techniek', maar voor een deelnemingsverplichting c.q. een bijdrageverplichting aan deze Mtfondsen en de toepasselijkheid van een arbeidsvoorwaarden-cao binnen de bedrijfstak Mt geldt het begrip 'werkgever in de bedrijfstak'. ${ }^{138}$

c Op grond van de definitie van het begrip 'werkgever in de bedrijfstak' dient een kwantitatieve vergelijking tussen de te onderscheiden bedrijfstakken binnen de bedrijfstak Mt plaats te vinden om te kunnen beoordelen in (bijvoorbeeld) welk opleidingsfonds binnen de bedrijfstak Mt de werkgever moet deelnemen en welke bc met arbeidsvoorwaarden binnen de bedrijfstak $\mathrm{Mt}$ van toepassing is.

d De Mt-regelingen vertonen dus (blijkens sub a) niet alleen een systematisch verband met andere bcp-regelingen, zoals de Me-regelingen en de Lb-regelingen, maar hebben tevens (blijkens sub b en c) onderling een systematisch verband.

e De Lb-regelingen hebben een structuur die verwant is aan die van de Mt-regelingen (en de Me-regelingen). Voor de Lb-regelingen geldt dat sprake is van toepasselijkheid van de vb Lb (voor het bpf) op een werkgever indien de werknemers van de werkgever uitsluitend of in hoofdzaak betrokken zijn bij in de kwalitatieve werkingssfeerbepalingen van de vb Lb beschreven werkzaamheden binnen (één of meer van) de vijftien takken van bedrijf in de bedrijfstak Lb.

f Indien de werknemers van (de betreffende onderneming van) de werkgever uitsluitend of in hoofdzaak betrokken zijn bij werkzaamheden behorend bij een van de (feitelijk) vijftien takken van bedrijf binnen de bedrijfstak Lb, dan zal op deze onderneming van de werkgever de werkingssfeer van een van de bc's (met normatieve arbeidsvoorwaarden) binnen de bedrijfstak Lb van toepassing kunnen zijn.

g Ten slotte zal voor de betreffende Lb-werkgever die tot een van de takken van bedrijf binnen de bedrijfstak Lb behoort, mogelijk een deelnemingsverplichting bestaan in bc LbSf (een sociaal fonds).

138 Voor het antwoord op de vraag of een werkgever kwalificeert als een 'werkgever in de bedrijfstak van het Metaalbewerkingsbedrijf (MtMb) dient (bijvoorbeeld) het aantal overeengekomen arbeidsuren van de werknemers betrokken bij werkzaamheden in de bedrijfstak MtMb te worden afgewogen tegen het aantal overeengekomen arbeidsuren van werknemers betrokken bij de afzonderlijke andere bedrijfstakken binnen de bedrijfstak Mt. Ingeval het aantal overeengekomen arbeidsuren van de in dienst zijnde werknemers die betrokken zijn bij werkzaamheden zoals uitgeoefend in enige afzonderlijke bedrijfstak in (binnen) de Mt gelijk is aan het aantal overeengekomen arbeidsuren van de in dienst zijnde werknemers die betrokken zijn bij werkzaamheden zoals uitgeoefend in enige andere afzonderlijke bedrijfstak in (binnen) de Mt, geeft de hoogte van de loonsommen van de betrokken werknemers in de maand januari de doorslag. Vgl. bc MtTi 2017/2019, artikel 4b en bc MtMb 2017/2019, artikel 4b. 
Uit het vorenstaande volgt dat de gesignaleerde 'variabelen' en 'werkingssferen' binnen en tussen de te onderscheiden bedrijfstakken als de bekende Russische poppetjes (een 'matroesjka') in elkaar passen. Hoe verhoudt zich nu het in deze bijdrage beschreven rekenmodel tot het in de literatuur en rechtspraak voorkomende criterium 'de kern en het zwaartepunt van de ondernemingsactiviteiten'?

\subsection{Rekenmodel versus 'de kern en het zwaartepunt van de ondernemingsactiviteiten'}

Bij de beoordeling van het werkingssfeercriterium 'in hoofdzaak' wordt in de literatuur en rechtspraak acht geslagen op 'de kern en het zwaartepunt van de ondernemingsactiviteiten'. ${ }^{139}$ Dit betreft geen werkingssfeercriterium dat in de bcpregelingen staat vermeld. Het is de vraag of het toepassen van dit criterium altijd het juiste antwoord oplevert.

In de zaak Adimec staat vast dat het door een aantal werknemers (op een assemblageafdeling) vervaardigen van camera's in de werkingssfeerbepalingen van de Me staat vermeld. ${ }^{140}$ De omzet wordt bij Adimec volledig behaald met het verkopen van de vervaardigde camera's. De arbeidsuren worden echter hoofdzakelijk toegerekend aan het (niet in de werkingssfeerbepalingen van de Me vermelde) ontwerpen en ontwikkelen van camera's door werknemers op een ontwikkelafdeling. ${ }^{141}$ Het gerechtshof stelt vast dat het ontwerpen en ontwikkelen van camera's de kern en het zwaartepunt van de ondernemingsactiviteiten vormen, zodat er geen bedrijfstakwerkzaamheden vallen aan te wijzen waaraan de assemblagewerkzaamheden kunnen worden toegerekend. ${ }^{142}$ Het gerechtshof oordeelt dat de Me-regelingen niet op Adimec van toepassing zijn. Het Adimec-arrest impliceert dat de werkzaamheden van de werknemers op de ontwikkelafdeling onvoldoende verband houden met de werkzaamheden van de werknemers op de assemblageafdeling. ${ }^{143}$ Het is mogelijk dat een (andere) rechter tot een ander oordeel komt indien overeenkomstig figuur 3 het door de ene groep werknemers ontwerpen en ontwikkelen van camera's kan worden gekwalificeerd als 'betrokken bij' het door de andere groep werknemers vervaardigen van de camera's.

Het sec toepassen van criteria zoals 'de kernactiviteit' en/of 'het zwaartepunt', ter beoordeling van de toepasselijke werkingssfeer van bcp-regelingen, kan tot een onjuiste uitkomst leiden. Illustratief is de zaak Bam Geleiderail. De A-G in die zaak knoopt aan bij het oordeel van het gerechtshof dat de kernactiviteiten van Bam Geleiderail (het aanleggen van stalen geleiderailconstructies) niet zozeer betrekking hebben op het bewerken van metaal (de bedrijfstak $\mathrm{Mt}$ ) als wel op het verrichten van meer omvattende werkzaamheden, namelijk het ontwerp en de

139 Asser/Lutjens 7-XI 2016/308 en 309.

140 NJ 2014/102 (Me/Adimec), r.o. 3.2.2 en 3.4.

141 De Me-regelingen vermelden thans (naast het 'vervaardigen') tevens uitdrukkelijk het 'ontwerpen' en het 'ontwikkelen'.

$142 \mathrm{Bij}$ de zaak Vector gaat het om het tegenovergestelde geval, te weten het 'toerekenen van uren van activiteiten die ondergeschikt zijn aan de bedrijfstakactiviteit'. NJ 2012/142 (Me/Vector).

143 Het gerechtshof merkt de ontwikkelactiviteit als een 'zelfstandig en nevengeschikt onderdeel' aan en niet als een activiteit die ten dienste staat van de assemblage. NJ 2014/102 (Me/Adimec), r.o. 3.2.3. 
aanleg van werken ter bevordering van de verkeersveiligheid (de bedrijfstak Bouwnijverheid, hierna: Bn). ${ }^{144}$ Net als het gerechtshof heeft de A-G kennelijk slechts oog voor de kwalitatieve criteria van de te onderscheiden bcp-regelingen. Indien de uitleg van de kwalitatieve werkingssfeerbepalingen door het gerechtshof al juist is (het meent dat de werkzaamheden onder zowel de Mt-regelingen als de Bn-regelingen vallen), dient het op grond van de kwantitatieve werkingssfeerbepalingen te bepalen of er sprake is van een deelnemingsverplichting in de Mt-regelingen dan wel de Bn-regelingen. Toepassing van deze kwantitatieve werkingssfeerbepalingen levert blijkens het arrest van het gerechtshof (in Den Haag, waarnaar de zaak door de Hoge Raad is verwezen) ${ }^{145}$ op dat de (overeengekomen arbeidsuren van) werknemers van Bam Geleiderail naar (absolute) hoofdzaak betrokken zijn bij het aanleggen, monteren, demonteren, onderhouden en herstellen van stalen vangrails. Deze werkzaamheden worden ingesloten door de kwalitatieve werkingssfeerbepalingen van de Mt-regelingen en (ook nog eens) uitgesloten door de kwalitatieve werkingssfeerbepalingen van de Bn-regelingen (welk laatste het gerechtshof te Amsterdam eveneens heeft miskend). ${ }^{146}$

\subsection{De irrelevante economische functie en de mogelijke relevantie van het doel}

Voor de beoordeling van de werkingssfeer zijn de werknemers van een werkgever die betrokken zijn bij werkzaamheden die onder de werkingssfeer van de bcp-regelingen vallen van belang. De zogenoemde economische functie van die werkzaamheden en/of de economische functie van de onderneming van de werkgever is niet relevant. ${ }^{147}$

De economische functie van een onderneming ziet op het 'verdienmodel', de wijze waarop deze omzet genereert. Dit dient bij de beoordeling van de werkingssfeer buiten beschouwing te worden gelaten. In de zaak Adimec wordt met de verkoop van de geassembleerde camera's de volledige omzet behaald. Op grond daarvan stellen de Me-fondsen dat de ontwikkelactiviteit als dienstbaar aan de assemblageactiviteit moet worden aangemerkt. ${ }^{148}$ Het aldus via het verdienmodel (de economische functie van de onderneming) koppelen van (de) werkzaamheden (assem-

144 NJ 2011/258 (Mt/Bam), onder 3.7. en 3.10.

145 NJ 2016/465 (Mt/Tussendiepen vh. Bam), r.o. 2.18: 'De grieven 3 tot en met 20 slagen.'

146 NJ 2016/465 (Mt/Tussendiepen vh. Bam), r.o. 2.12. Anders: Koot-van der Putte, Collectieve arbeidsvoorwaarden en individuele contractsvrijheid (Monografieën sociaal recht, nr. 42), Deventer: Wolters Kluwer 2015, p. 52 en 53. Koot-van der Putte benoemt overigens de Me-regelingen, maar zal de Mt-regelingen bedoelen. Zowel bij NJ 2011/258 (Mt/Bam) als bij Kantonrechter Tilburg 18 juli 2012, ECLI:NL:RBBRE:2012:BX2990 (Bn/Vevon) waren enerzijds de Mtregelingen en anderzijds de Bn-regelingen aan de orde.

147 De economische functie komt middels een 'omzet'-criterium wel voor in andere bcp-regelingen zoals vb Groothandel in levensmiddelen (Stcrt. 16 februari 2017, 9472, artikel 2 lid 1). Schematisch is de economische functie van de onderneming in de buitenste schil van het model in figuur 3 weergegeven.

148 NJ 2014/102 (Me/Adimec), r.o. 3.3. 
bleren en ontwikkelen) is in het licht van het vorenstaande niet juist. De Hoge Raad is daar ook niet in meegegaan. ${ }^{149}$

Zoals gezegd, is de toepasselijkheid van de behandelde bcp-regelingen eveneens onafhankelijk van de economische functie van de werkzaamheden van de werknemers. Dit betekent dat de wijze waarop en de efficiëntie waarmee de werkzaamheden door de werknemers worden uitgeoefend ook niet relevant is. ${ }^{150}$ In de zaak Unis zijn de werknemers van Unis betrokken bij het herstellen van elektrotechnische onderdelen (zoals printplaten). ${ }^{151}$ Het gerechtshof te Den Haag koppelt (overigens ook in strijd met figuur 3) ten onrechte met toepassing van de economische functie werkzaamheden van dezelfde werknemer(s) $l o s .{ }^{152}$ De werkzaamheden van dezelfde werknemer(s) worden gesplitst in het analyseren (van het gebrek), het repareren (van het gebrek) en het testen (van het gerepareerde onderdeel). Dit terwijl het wel zo doelmatig (economisch: efficiënt: praktisch) is om eerst een gebrek op te zoeken (te analyseren), vervolgens te repareren en ten slotte te onderzoeken of de uitgevoerde reparatie is geslaagd (te testen). Het gerechtshof houdt derhalve ten onrechte rekening met de economische functie van zowel het analyseren als het testen. Het is niet van belang dat voorbereidende en achteraf controlerende werkzaamheden van werknemers meer arbeidstijd in beslag nemen dan de tijd die gemoeid is met de daadwerkelijke reparatie van een zaak. Ook kan mede in aanmerking worden genomen dat Unis uitsluitend het herstellen van elektrotechnische onderdelen tot doel heeft. ${ }^{153}$ Ten slotte geldt dat, anders dan in de zaak Adimec, de analyseactiviteit en de testactiviteit niet als een 'zelfstandig en nevengeschikt onderdeel' aangemerkt kunnen worden, eenvoudigweg omdat alle werkzaamheden door dezelfde werknemer(s) worden uitgeoefend, alsook omdat deze activiteiten ten dienste staan van (betrokken zijn bij)

149 De omzet kan wel als (bijkomende) omstandigheid bij de beoordeling van de werkingssfeer relevant zijn. Bijvoorbeeld indien de arbeidsuren van de werknemers in rekening worden gebracht bij een opdrachtgever in het kader van een vervaardigd product of een geleverde dienst.

150 Van Dale. Economie (de (v.)) 1 (g. mv.) zuinigheid, bezuiniging. Economisch (bn.) 1 spaarzaam, zuinig, doelmatig (m.n. in technische toepassingen): economisch te werk gaan, met spaarzaam gebruik van kracht of geld. Efficiëntie (de (v.); g. mv.) het verkrijgen van het grootst mogelijk effect of resultaat met of uit een gegeven kracht, middel of toestand, m.n. de rationele toepassing van economische principes in het bedrijfsleven, syn. doeltreffendheid, doelmatigheid, efficiency. Doelmatig (bn.) in overeenstemming met, geschikt voor het doel waartoe het gemaakt is, syn. efficiënt, functioneel, praktisch: het huis is zeer doelmatig ingericht. Functie (de (v.)) 3 bijzondere werking en verrichting: de functie uitoefenen, vervullen van -, als zodanig werken; - ook als tweede lid in samenst. als de volgende, waarin het eerste lid een handeling of werking noemt: ademhalingsfunctie, denkfunctie, leesfunctie, schrijffunctie, voortplantingsfunctie; - ook als tweede lid in samenst. als de volgende, waarin het eerste lid een orgaan noemt (dat een bepaalde functie heeft): hartfunctie, hersenfunctie, leverfunctie, miltfunctie, nierfunctie, schildklierfunctie 4 (psych.) geestelijk vermogen of werking van de geest (zoals denken, spreken, bewegen) 5 (wisk.) veranderlijke grootheid die als zodanig van een of meer andere afhangt.

151 Vgl. figuur 3.

152 PJ 2017/111 (Mt/Unis). De auteur is weliswaar niet als advocaat betrokken geweest bij de feitelijke instanties, maar is wel voor de Mt-fondsen betrokken bij de cassatieprocedure. Bij het ter perse gaan van deze bijdrage wordt bekend dat de Hoge Raad het arrest van het Gerechtshof Den Haag heeft vernietigd (HR 21 december 2018, ECLI:NL:HR:2018:2363).

153 PJ 2011/50, r.o. 4.1.b. en 4.11.1. (Mt/Mimeos). 
het repareren van de elektrotechnische onderdelen. Een andere uitleg zal het ontgaan van de bcp-regelingen en daarmee concurrentie op arbeidsvoorwaarden in de hand werken. ${ }^{154}$

Anders dan in de zaak Unis lijkt het gerechtshof te Den Haag in de eerdergenoemde (verwijzings)zaak Bam Geleiderail het 'doel van de onderneming'155 en in mindere mate het gebleken feit dat 'de werknemers in hoofdzaak betrokken zijn bij werkzaamheden' die onder de werkingssfeer van de Mt-regelingen vallen, van belang te achten. ${ }^{156} \mathrm{Het}$ is een nuance, maar geen onbelangrijke. In lijn met de relevante werkingssfeerbepalingen dienen immers de (werkzaamheden van) werknemers aan werkingssfeerbepalingen van bcp-regelingen te worden toebedeeld. Daaruit zal dan in beginsel het doel (de gerichtheid en hoofdactiviteit) van de onderneming moeten voortvloeien en niet andersom. Het doel van de onderneming kan wel als bijkomende omstandigheid voor de beoordeling van de werkingssfeer relevant zijn. Ook de Hoge Raad lijkt in de zaak Van der Tas ${ }^{157}$ vooral waarde te hechten aan de werkzaamheden van de werknemers en derhalve niet zozeer aan het doel van de onderneming, te weten het uitzenden van deze werknemers. Ten slotte is dit laatste, zoals gezegd, in de zaak C4C onterecht onderbelicht gebleven. ${ }^{158}$

\section{5}

\section{Conclusie}

De toepasselijkheid van de werkingssfeer van de bedrijfstakken Lb en Me vereist dat de overeengekomen arbeidsuren van de werknemers die betrokken zijn bij de te onderscheiden bedrijfstakwerkzaamheden meer dan $50 \%$ van het totale aantal overeengekomen arbeidsuren binnen de onderneming van de werkgever uitmaken. Wordt aan dit 'uitsluitend of in absolute hoofdzaak'-criterium (een > 50\%criterium) voldaan, dan kwalificeert de onderneming als een werkgever binnen ofwel de bedrijfstak Lb, ofwel binnen de bedrijfstak Me. De werkingssfeer van de na de Lb-regelingen en de Me-regelingen tot stand gekomen Mt-regelingen is afgebakend van de Me-regelingen door middel van spiegelbeeldige kwalitatieve en kwantitatieve samenloopbepalingen. Zo vertonen de Mt-regelingen en de $\mathrm{Me}$ regelingen een spiegelbeeldig verband met elkaar op het gebied van de bedrijfstak van het Metaalbewerkingsbedrijf en onderdelen van de bedrijfstak van het Technisch Installatiebedrijf. Na de Mt-regelingen zijn vele andere bcp-regelingen tot stand gekomen, waarmee de Mt-regelingen hun werkingssfeer afbakenen middels een generieke bepaling ter voorkoming van samenlopende werkingssferen. Op grond van deze bepaling is het voor de beoordeling van het al dan niet van toepas-

154 Vgl. Toetsingskader-bpf, onder 1 en Toetsingskader-avv, onder 1.

155 NJ 2016/465 (Mt/Tussendiepen vh. Bam), r.o. 2.12. Het gerechtshof spreekt van 'gericht op' en 'hoofdactiviteit' en 'het uitvoeren van werken met betrekking tot stalen voorwerpen'.

156 NJ 2016/465 (Mt/Tussendiepen vh. Bam), r.o. 2.12: 'Vast staat voorts dat binnen het bedrijf van Geleiderail het uitvoeren van de bedoelde werken met betrekking tot stalen voorwerpen, ook wat personeelsinzet betreft (aantal werknemers en arbeidsuren), de hoofdmoot van de werkzaamheden van Geleiderail vormde.'

157 HR 15 april 2011, ECLI:NL:HR:2011:BP6601, r.o. 3.1, NJ 2011/181 (Mt/Van der Tas).

158 Halsema 2016. 


\section{Figuur 7 De kwantitatieve criteria van de oudste drie bedrijfstakken}

\begin{tabular}{|l|lll|}
\hline Bedrijfstak & Criterium & Telling 1 ('a') & Telling 2 ('u') \\
\hline $\mathrm{Lb}$ & $\begin{array}{l}\text { Uitsluitend of } \\
\text { in hoofdzaak }\end{array}$ & $\begin{array}{l}\text { Werknemers } \\
\text { betrokken bij }\end{array}$ & $\begin{array}{l}\text { Overeengekomen } \\
\text { arbeidsuren }\end{array}$ \\
$\mathrm{Me}$ & $\begin{array}{l}\text { Uitsluitend of } \\
\text { in hoofdzaak }\end{array}$ & $\begin{array}{l}\text { Werknemers } \\
\text { betrokken bij }\end{array}$ & $\begin{array}{l}\text { Overeengekomen } \\
\text { arbeidsuren }\end{array}$ \\
\hline $\mathrm{Mt}$ & $\begin{array}{l}\text { Uitsluitend of } \\
\text { in hoofdzaak }\end{array}$ & $\begin{array}{l}\text { Werknemers } \\
\text { betrokken bij }\end{array}$ & $\begin{array}{l}\text { Overeengekomen } \\
\text { arbeidsuren }\end{array}$ \\
\hline
\end{tabular}

sing zijn van de werkingssfeer van de Mt-regelingen noodzakelijk dat er een kwalitatieve en kwantitatieve afweging van werkingssferen tussen enerzijds de bedrijfstak Mt en anderzijds de andere afzonderlijke bedrijfstakken buiten de bedrijfstak Mt plaatsvindt (waaronder de bedrijfstak Lb en de bedrijfstak Me). Deze afweging van werkingssferen tussen te onderscheiden (afzonderlijke) bedrijfstakken kan tot gevolg hebben dat een werkgever naar relatieve hoofdzaak (een $\leq 50 \%$ - of $\geq 50 \%$-criterium) kwalificeert als een werkgever binnen de bedrijfstak Mt. Voor de vaststelling van de toepasselijke werkingssfeer van de bcp-regelingen in de bedrijfstakken Lb, Me en Mt dienen eerst per te onderscheiden (afzonderlijke) bedrijfstak de werknemers die bij de te onderscheiden bedrijfstakwerkzaamheden betrokken zijn, te worden (op)geteld. Vervolgens dienen per te onderscheiden (afzonderlijke) bedrijfstak de met de werknemers overeengekomen arbeidsuren te worden opgeteld. Door middel van een (kwalitatieve en) kwantitatieve afweging tussen de te onderscheiden bedrijfstakken kan worden vastgesteld welke bcp-regelingen op de werkgever van toepassing zijn. Deze rekenmethode kan zowel op een rechtspersoon als op een onderdeel (zoals een afdeling of een vestiging) van een rechtspersoon worden toegepast.

Noch de economische functie van de werkzaamheden van de werknemers (de efficiëntie waarmee die werkzaamheden worden uitgeoefend), noch de economische functie van de onderneming van de werkgever (het verdienmodel) is van belang voor de vaststelling van de toepasselijke werkingssfeer van deze bcp-regelingen. De door een werkgever op grond van artikel 7:655 BW aan een werknemer te verstrekken informatie over de functie van de werknemer (of de aard van zijn arbeid) en de gebruikelijke arbeidsduur (per dag of per week) is van belang voor de beoordeling van de toepasselijke werkingssfeer van bcp-regelingen op een werkgever. De functie van de werknemer en de daarmee gemoeide werkzaamheden ('arbeid': ' $a$ ') en de met deze werknemer voltijds dan wel deeltijds overeengekomen arbeidsuren ('uren': 'u') zullen steeds (als variabelen) aan een afzonderlijke bedrijfstak kunnen worden toegerekend ter vaststelling van de op de werkgever toepasselijke werkingssfeer van bcp-regelingen ('W'). 
Figuur 8 Het rekenmodel voor de oudste drie bcp-regelingen

$$
\begin{aligned}
& W_{L b}=a_{L b} \times u_{L b} \\
& W_{M e}=a_{M e} \times u_{M e} \\
& W_{M t}=a_{M t} \times u_{M t} \\
& W_{L b}: W_{M e}: W_{M t}=W
\end{aligned}
$$

Door deze kwalitatieve en kwantitatieve afweging tussen te onderscheiden (afzonderlijke) bedrijfstakken kan worden berekend en vastgesteld bij welke bedrijfstak de werknemers van de (onderneming van de) werkgever in hoofdzaak betrokken zijn en in welke bcp-regelingen om die reden voor deze werkgever een wettelijke deelnemingsverplichting bestaat. Het in deze bijdrage beschreven rekenmodel $(W=a \times u)$ zal van belang zijn voor de uitleg van de werkingssfeer van de overige in figuur 2 vermelde bedrijfstakken. Het is hierbij de vraag of sprake zal kunnen zijn van een universeel model voor de berekening van de werkingssfeer van bcpregelingen binnen de te onderscheiden bedrijfstakken.

\section{Figuur 9 De 'universele kwantor'}

$\boldsymbol{\forall}$ is de 'universele kwantor', $\forall \mathrm{W} \mid$ betekent 'voor alle werkingssfeervraagstukken geldt'

Een 'bedrijf' wordt (globaal) gedefinieerd als 'een onderneming die zich bezighoudt met het maken en/of verhandelen van bepaalde goederen en/of het leveren van bepaalde diensten'. ${ }^{159}$ Deze drie kernelementen van het begrip 'bedrijf' (eenvoudig gezegd: 'productie', 'handel' en 'dienstverlening') vinden tevens hun weerslag in de in figuur 2 vermelde bedrijfstakken met bcp-regelingen. De in deze bijdrage behandelde drie bedrijfstakken Lb, Me en Mt kunnen in de kern als overwegend 'productiegericht' worden gezien. Vanzelfsprekend kan er binnen een overwegend 'productiegerichte' bedrijfstak (of onderneming) tevens handel en/of dienstverlening plaatsvinden. Vaak zal de toepasselijke werkingssfeer dan kunnen worden berekend aan de hand van de inmiddels bekende variabelen 'arbeid' ('a') en 'overeengekomen arbeidsuren' ('u'), zoals bij de drie in deze bijdrage behandelde bedrijfstakken. Met betrekking tot later ontstane bcp-regelingen, behorende bij bedrijfstakken waar het accent ligt op 'handel' en/of 'dienstverlening', zal daarnaast eventueel een 'omzet'-criterium (hierna: 'o') en/of 'loonsom'-criterium (hierna: 'l') hebben te gelden.

\section{Figuur 10 Een grondslag voor een universeel rekenmodel voor alle bcp- regelingen?}


Het hiervoor vermelde rekenmodel zal kunnen dienen als belangrijke basis voor een rekenmodel voor alle bcp-regelingen in Nederland. Het uiteindelijke, universele rekenmodel zal dan, naast de kernvariabelen 'arbeid' ('a') en 'overeengekomen arbeidsuren' ('u') bijvoorbeeld tevens variabelen zoals 'o' en/of 'l' kunnen bevatten. ${ }^{160}$

\section{Bijlage met een overzicht van de drie bedrijfstak(cao- en pensioen)regelingen in 2017}

1.

\section{Landbouw}

\section{Bedrijfstakpensioenregeling Landbouw}

a Vb Landbouw (vb Lb, Stcrt. 1 mei 2017, nr. 25021).

\section{Collectieve arbeidsovereenkomsten Landbouw}

a Cao voor de Glastuinbouw (bc LbGt 2016/2018, Stcrt. 13 oktober 2016, nr. 47587).

b Cao Groothandel in Bloembollen (bc LbGb 2016/2018, Stcrt. 3 november 2016, nr. 48943).

c Cao voor het Hoveniersbedrijf in Nederland (bc LbHb 2016/2018, Stcrt. 28 oktober 2016, nr. 48926).

d Cao voor de Open Teelten (bc LbOt 2016/2017, Stcrt. 29 november 2016, nr. 49251).

e Cao Landbouwwerktuigen Exploiterende Ondernemingen (bc LbLe 2016/2017, Stcrt. 28 oktober 2016, nr. 49920).

f Cao voor de Productiegerichte Dierhouderij (bc LbDh 2014/2017, Strct. 10 juli 2017, nr. 32708).

g Cao Groenten- en Fruitverwerkende Industrie (bc LbGfi 2016, Stcrt. 19 februari 2016, nr. 2769).

h Cao voor de Groenvoederdrogerijen (bc LbGd 2016/2018, niet algemeen verbindend verklaard).

i Cao voor de Tuinzaadbedrijven (bc LbTb 2016/2017, niet algemeen verbindend verklaard).

j Raam-Cao Bos en Natuur (bc LbBn 2016/2017, niet algemeen verbindend verklaard).

160 De Mt-regelingen vermelden overigens eveneens een variabele ' '. Indien immers ( $a \times u$, te weten) het aantal overeengekomen arbeidsuren van de in dienst zijnde werknemers die betrokken zijn bij werkzaamheden zoals uitgeoefend in enige afzonderlijke bedrijfstak binnen de Mt gelijk is aan ( $a \times u$, te weten) het aantal overeengekomen arbeidsuren van de in dienst zijnde werknemers die betrokken zijn bij werkzaamheden zoals uitgeoefend in enige andere afzonderlijke bedrijfstak binnen de Mt, geeft de hoogte van de loonsommen van de betrokken werknemers $(l)$ in de maand januari de doorslag voor de toepasselijkheid van de bc met normatieve arbeidsvoorwaarden en de bc voor bijvoorbeeld het opleidingsfonds. Hieruit volgt een relatie tussen variabele 'l' en variabele 'a'. Vgl. bc MtTi 2017/2019, artikel 4b en bc MtMb 2017/2019, artikel 4b met betrekking tot 'werkgever in de bedrijfstak'. 
k Cao Bedrijfsverzorgingsdiensten (bc LbBd 2013/2016, niet algemeen verbindend verklaard).

1 Cao voor de Varkensverbetering in Nederland (bc LbVv 2013, niet algemeen verbindend verklaard).

m Cao voor de Rundveeverbetering in Nederland (bc LbRv 2009, niet algemeen verbindend verklaard).

n Cao in de Bedrijfstak Cultuurtechnische Werken (bc LbCt 2005/2006, niet algemeen verbindend verklaard).

o Cao Paddestoelen (bc LbP 2003, niet algemeen verbindend verklaard).

\section{Bedrijfstakfondsen-cao's Landbouw}

a Cao voor de Agrarische en Aanverwante Sectoren inzake Sociaal Fonds Colland Arbeidsmarkt (bc LbSf 2014/2019, Stcrt. 30 juni 2014, nr. 15551).

b Cao inzake Vrijwillig Vervroegde Uittreding voor de Groenten- en Fruitverwerkende Industrie (bc LbGfiVut 2011/2014, Stcrt. 29 december 2010, nr. 19405).

c Cao inzake vervroegde uittreding agrarische sectoren (bc LbVut 2010/2014, Stcrt. 19 augustus 2010, nr. 13081).

d Cao Overbruggingsfonds Agrarische Sectoren (bc LbOf 2014/2018, niet algemeen verbindend verklaard).

e Cao inzake Aanvulling Uitkering Oudere Werknemer Agrarische sectoren (bc LbAu 2015/2017, niet algemeen verbindend verklaard).

\section{Metalektro}

\section{Bedrijfstakpensioenregeling Metalektro}

a Vb Metalektro (vb Me, Stcrt. 13 september 2016, nr. 48548).

\section{Collectieve arbeidsovereenkomsten Metalektro}

a Cao in de Metalektro (bc Me 2016/2018, Stcrt. 15 juli 2016, nr. 30758).

b Cao voor het Hoger Personeel in de Metalektro (bc MeHp 2016/2018, Stcrt. 3 augustus 2016, nr. 35630).

c Aanvullende Cao in de Metalektro betreffende het Systeem voor Arbeidsomstandigheden (bc MeSa 2015/2018, niet algemeen verbindend verklaard).

\section{Bedrijfstakfondsen-cao Metalektro}

a Cao in de Metalektro inzake Arbeidsmarkt en Opleiding (bc MeAo 2016/2018, Stcrt. 7 juli 2016, nr. 30755).

\section{Metaal en Techniek}

Bedrijfstakpensioenregeling Metaal en Techniek

a Vb Metaal en Techniek (vb Mt, Stcrt. 28 april 2015, nr. 11859). 
Collectieve arbeidsovereenkomsten Metaal en Techniek

a Cao voor het Technisch Installatiebedrijf (bc MtTi 2017/2019, Stcrt. 16 augustus 2017, nr. 40192).

b Cao voor de Goud- en Zilvernijverheid (bc MtGz 2017/2019, Stcrt. 16 augustus 2017, nr. 40230).

c Cao voor het Metaalbewerkingsbedrijf (bc MtMb 2017/2019, Stcrt. 16 augustus 2017, nr. 40197).

d Cao voor het Carrosseriebedrijf (bc MtCb 2017/2019, Stcrt. 16 augustus 2017, nr. 40200).

e Cao voor het Isolatiebedrijf (bc MtIb 2017/2019, Stcrt. 16 augustus 2017, nr. 40254).

f Cao voor het Motorvoertuigenbedrijf en Tweewielerbedrijf (bc MtMt 2017/2018, Stcrt. 23 februari 2017, nr. 10916).

g Cao voor de Zeilmakerijen, Dekkledenvervaardiging, Dekkledenverhuur, Scheepstuigerijen en de scheepsbenodigdhedenhandel (bc MtZd 2016/2017, Stcrt. 15 juli 2016, nr. 27075).

h Cao voor Tankstations en Wasbedrijven (bc MtTw 2016/2017, Stcrt. 8 september 2016, nr. 42511).

\section{Bedrijfstakfondsen-cao's Metaal en Techniek}

a Cao Opleidings- en Ontwikkelingsfonds voor het Technisch Installatiebedrijf (bc Otib 2015/2019, Stcrt. 25 februari 2015, nr. 2121).

b Cao voor de Goud- en Zilvernijverheid inzake Opleidings- en Ontwikkelingsfonds (bc Ogz 2015/2019, Stcrt. 30 december 2014, nr. 35124).

c Cao voor het Metaalbewerkingsbedrijf inzake Opleidings- en Ontwikkelingsfonds (bc Oom 2015/2019, Stcrt. 14 januari 2015, nr. 1181).

d Cao Opleidings- en Ontwikkelingsfonds voor het Carrosseriebedrijf (bc Ooc 2015/2019, Stcrt. 30 december 2014, nr. 35137).

e Cao Opleidings- en Ontwikkelingsfonds voor het Isolatiebedrijf (bc Ooi 2015/2019, Stcrt. 30 december 2014, nr. 35133).

f Cao Bijdragefonds Tankstations en Wasbedrijven (bc Btw 2015/2019, Stcrt. 5 december 2014, nr. 30752).

g Cao Opleidings- en Ontwikkelingsfonds Tankstations en Wasbedrijven (bc Ootw 2015/2019, Stcrt. 5 december 2014, nr. 30761).

h Cao Aanvullend Invaliditeitspensioen Metaal en Techniek (bc Avim 2014/2018, Stcrt. 16 januari 2014, nr. 1397).

i Cao werkgeversbijdrage Sociaal Fonds Metaal en Techniek (bc Sfm 2014/2018, Stcrt. 27 december 2013, nr. 33694).

j Cao Motorvoertuigenbedrijf en Tweewielerbedrijf Sociaal Fonds (bc Sfmt 2014/2018, Stcrt. 11 december 2013, nr. 31727).

$\mathrm{k}$ Cao voor het Opleidings- en Ontwikkelingsfonds voor het Motorvoertuigenbedrijf en Tweewielerbedrijf (bc Oomt 2012/2016, Stcrt. 28 november 2011, nr. 19558). 